\title{
Dangers of hyperoxia
}

\author{
Mervyn Singer ${ }^{1}$, Paul J. Young ${ }^{2,3}$, John G. Laffey ${ }^{4}$, Pierre Asfar ${ }^{5}$, Fabio Silvio Taccone ${ }^{6}$, Markus B. Skrifvars ${ }^{7}$, \\ Christian S. Meyhoff ${ }^{8}$ and Peter Radermacher ${ }^{9^{*}}$ (D)
}

\begin{abstract}
Oxygen $\left(\mathrm{O}_{2}\right)$ toxicity remains a concern, particularly to the lung. This is mainly related to excessive production of reactive oxygen species (ROS). Supplemental $\mathrm{O}_{2}$, i.e. inspiratory $\mathrm{O}_{2}$ concentrations $\left(\mathrm{F}_{1} \mathrm{O}_{2}\right)>0.21$ may cause hyperoxaemia (i.e. arterial (a) $\mathrm{PO}_{2}>100 \mathrm{mmHg}$ ) and, subsequently, hyperoxia (increased tissue $\mathrm{O}_{2}$ concentration), thereby enhancing ROS formation. Here, we review the pathophysiology of $\mathrm{O}_{2}$ toxicity and the potential harms of supplemental $\mathrm{O}_{2}$ in various ICU conditions. The current evidence base suggests that $\mathrm{PaO}_{2}>300 \mathrm{mmHg}(40 \mathrm{kPa}$ ) should be avoided, but it remains uncertain whether there is an "optimal level" which may vary for given clinical conditions. Since even moderately supra-physiological $\mathrm{PaO}_{2}$ may be associated with deleterious side effects, it seems advisable at present to titrate $\mathrm{O}_{2}$ to maintain $\mathrm{PaO}_{2}$ within the normal range, avoiding both hypoxaemia and excess hyperoxaemia.

Keywords: Hyperoxia, Hyperoxaemia, Reactive oxygen species, Reactive nitrogen species, ARDS, Sepsis, Traumaand-haemorrhage, Traumatic brain injury, Subarachnoidal bleeding, Acute ischaemic stroke, Intracranial bleeding, Cardiopulmonary resuscitation, Myocardial infarction, Surgical site infection
\end{abstract}

\section{Background}

Since its discovery [1-3], oxygen $\left(\mathrm{O}_{2}\right)$ has been recognised as "friend and foe" [4]. It is vital for aerobic respiration within the mitochondria, yet mitochondrial respiration also forms reactive oxygen species (ROS) [5], production of which relates to $\mathrm{O}_{2}$ concentration [6-8]. Supplemental $\mathrm{O}_{2}$, i.e. inspiratory $\mathrm{O}_{2}$ concentrations $\left(\mathrm{F}_{\mathrm{I}} \mathrm{O}_{2}\right)>0.21$, may cause hyperoxaemia (arterial $\mathrm{PO}_{2}>100 \mathrm{mmHg}$ ) and subsequently increased ROS formation [9-11]. This is particularly pronounced during ischaemia/reperfusion (I/R) and/or hypoxia/re-oxygenation [6-8]. ROS are as "Janus-headed" as $\mathrm{O}_{2}$ : ROS are vital for host defence, and also toxic [12]. Consequently, $\mathrm{O}_{2}$ toxicity, especially pulmonary, is a matter of concern [13-15], and optimal dosing remains unclear in critical care. This review discusses potential harms of $\mathrm{O}_{2}$ in various underlying critical illnesses. Figure 1 summarises the

\footnotetext{
${ }^{*}$ Correspondence: peter.radermacher@uni-ulm.de

${ }^{9}$ Institut für Anästhesiologische Pathophysiologie und

Verfahrensentwicklung, Universitätsklinikum, Helmholtzstrasse 8-1, 89081 Ulm, Germany

Full list of author information is available at the end of the article
}

possible dangers of hyperoxia, highlighting pathophysiological mechanisms and their impact on specific disease conditions. The most important clinical studies are listed in Table 1; "Additional file 1" shows the complete study list.

\section{Pathophysiology}

Oxygen generally exists as di-atomic molecule $\left(\mathrm{O}_{2}\right)$; its two atoms bond to each other through single bonds leaving two unpaired electrons. $\mathrm{O}_{2}$ performs its actions through these unpaired electrons which act as radicals. ROS are even more reactive molecules formed through oxygen's electron receptivity (e.g. superoxide, peroxide, and hydroxyl anion).

Over $90 \%$ of $\mathrm{O}_{2}$ consumption is utilised by mitochondria, predominantly for ATP production (oxidative phosphorylation), but also for heat generation through uncoupling, and superoxide production. $\mathrm{O}_{2}$ is the terminal electron acceptor at Complex IV of the electron transport chain (ETC), being reduced to water in this process. For each mole of glucose metabolised, anaerobic respiration (glycolysis) generates only 2 ATP moles compared to approximately 28-30 from oxidative phosphorylation. In original author(s) and the source, provide a link to the Creative Commons licence, and indicate if changes were made. The images or other third party material in this article are included in the article's Creative Commons licence, unless indicated otherwise in a credit line to the material. If material is not included in the article's Creative Commons licence and your intended use is not permitted by statutory regulation or exceeds the permitted use, you will need to obtain permission directly from the copyright holder. To view a copy of this licence, visit http://creativecommons.org/licenses/by/4.0/. The Creative Commons Public Domain Dedication waiver (http://creativeco mmons.org/publicdomain/zero/1.0/) applies to the data made available in this article, unless otherwise stated in a credit line to the data. 


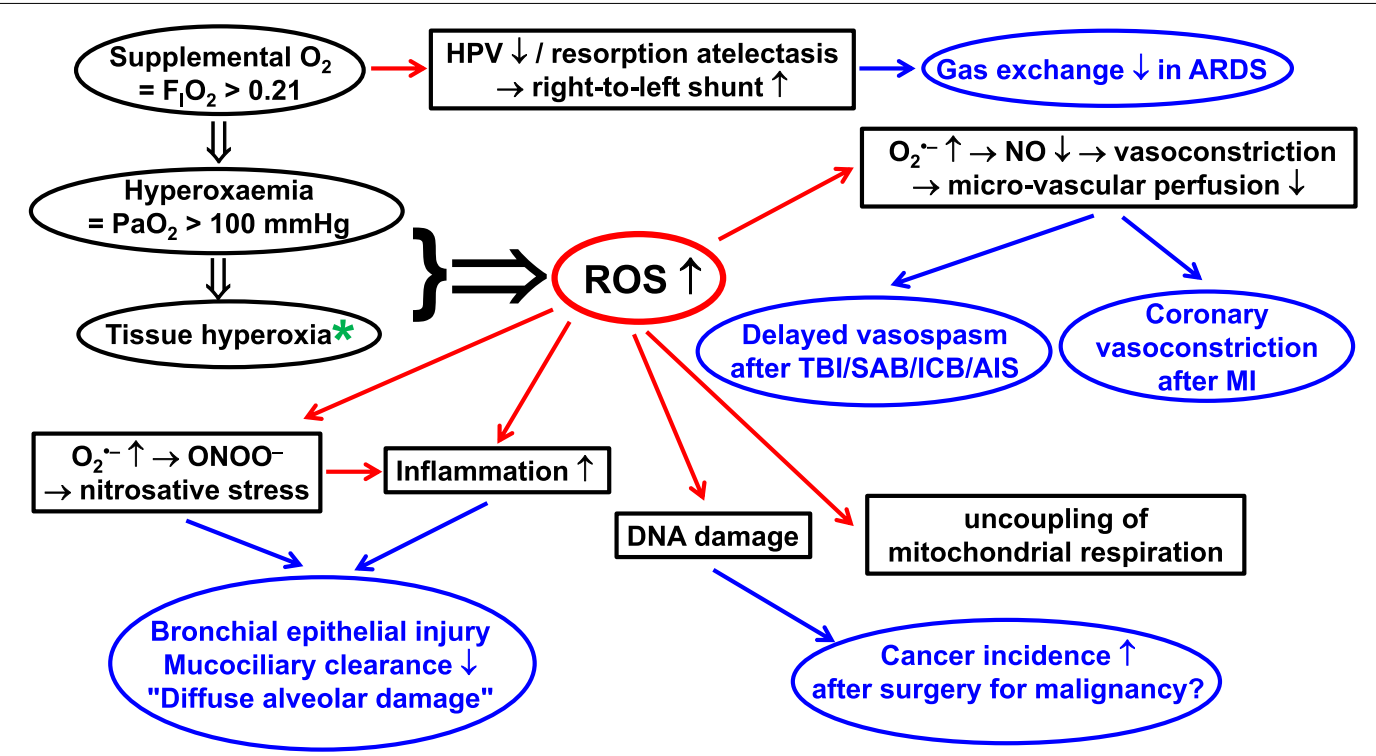

Fig. 1 Potential harm of hyperoxia. AIS acute ischaemic stroke; MI myocardial infarction; ARDS acute respiratory distress syndrome; $\mathrm{F}_{1} \mathrm{O}_{2}$ fraction of inspired $\mathrm{O}_{2} ; \mathrm{HPV}$ hypoxic pulmonary vasoconstriction; ICB intracranial bleeding; $\mathrm{PaO}_{2}$ arterial $\mathrm{O}_{2}$ partial pressure; $\mathrm{NO}$ nitric oxide; $\mathrm{ONOO}^{-}$ peroxynitrite; $\mathrm{O}_{2}{ }^{-}$superoxide anion; $\mathrm{ROS}$ reactive oxygen species; $\mathrm{SAB}$ subarachnoidal bleeding; TBI traumatic brain injury. ${ }^{*}$ Note that while hyperoxia and hyperoxaemia are well defined as $\mathrm{F}_{1} \mathrm{O}_{2}>0.21$ and $\mathrm{PaO}_{2}>100 \mathrm{mmHg}$, respectively, there is no general threshold for "tissue hyperoxia", because the normal tissue $\mathrm{PO}_{2}$ depends on the macro- and microcirculatory perfusion and the respective metabolic activity. Nevertheless, it is noteworthy that $\mathrm{PO}_{2}$ levels as low as $0.3-0.7 \mathrm{mmHg}$ suffice for correct functioning of the mitochondrial respiratory chain $[17,162]$

health, 1-3\% of mitochondrial $\mathrm{O}_{2}$ consumption is used at the ETC Complexes I and III to generate superoxide, an important signalling molecule [16]. Superoxide is necessary for enzyme processes, e.g. oxidases (catalysing oxidation-reduction reactions) and oxygenases (incorporating oxygen into a substrate). Activated immune cells utilise $\mathrm{O}_{2}$ for extra-mitochondrial ROS production: NADPH oxidase generates superoxide ("respiratory burst") for phagocytosis. Unless overwhelmed by ROS over-production, antioxidant capacity (e.g. superoxide dismutase, glutathione, thioredoxin) prevents oxidative damage to DNA, proteins and lipids, and subsequent cell death.

$\mathrm{O}_{2}$ also affects the inflammatory response. Experimental models and volunteer and patient studies demonstrate that hyperoxia (and hypoxia) can induce pro- and antiinflammatory responses, with both protective and harmful sequelae [17]. Hyperbaric oxygen is used to aid wound healing and treat gas gangrene, but may cause neurotoxicity. Whether the response to hyperoxia relates to its degree and/or duration, specific cell types, background inflammation, or other factors remains uncertain; clearly, $\mathrm{O}_{2}$ toxicity can be induced de novo without underlying pathology, predominant organs being lung, brain, and eye.

Pulmonary toxicity was first described by Lorrain Smith: pure $\mathrm{O}_{2}$ at hyperbaric pressures caused inflammatory pneumonitis [18]. At atmospheric pressure pneumonitis was seen after days in non-human primates breathing $60-100 \% \mathrm{O}_{2}$ [19-21]. After initially affecting the airways (tracheobronchitis) with reduced mucociliary clearance [22], the lung parenchyma becomes involved. In humans, this occurs especially when the inspiratory $\mathrm{PO}_{2}$ is significantly enhanced in a hyperbaric environment. Initial complaints are retrosternal chest pain, then coughing and dyspnoea as a pneumonitis develops with pulmonary oedema and diffuse radiological lung shadowing. In healthy volunteers breathing $98-100 \% \mathrm{O}_{2}$, chest pain commenced after $14 \mathrm{~h}$, coughing and dyspnoea between 30 and $74 \mathrm{~h}$ [22]. Due to nitrogen washout [23], there may also be atelectasis in lung regions with low ventilation/perfusion ratios [24].

Whether hyperbaric $v s$. normobaric $\mathrm{O}_{2}$ toxicity mechanisms and onset are similar is unclear. Pulmonary injury was accelerated by hyperbaric hyperoxia, but was less inflammatory in character and driven by a neurogenic component that could be blocked by inhibiting neuronal nitric oxide synthase or vagal nerve transection [25]. Possible synergistic effects on $\mathrm{O}_{2}$ toxicity of underlying lung pathology are poorly characterised, especially at the more moderate degrees of hyperoxia inflicted on patients. This is, however, well-recognised with bleomycin toxicity where mild hyperoxia may be damaging [26]. 


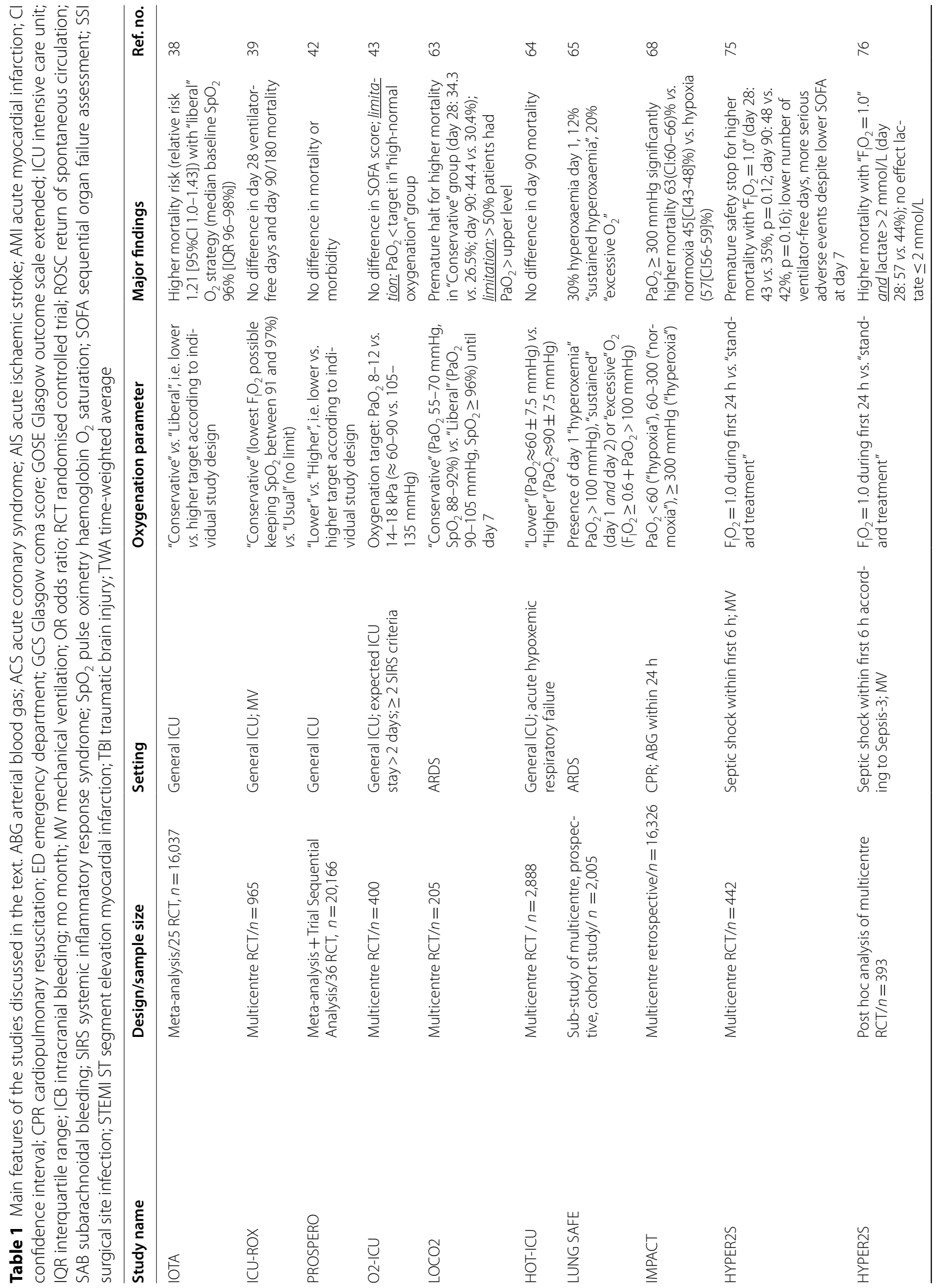




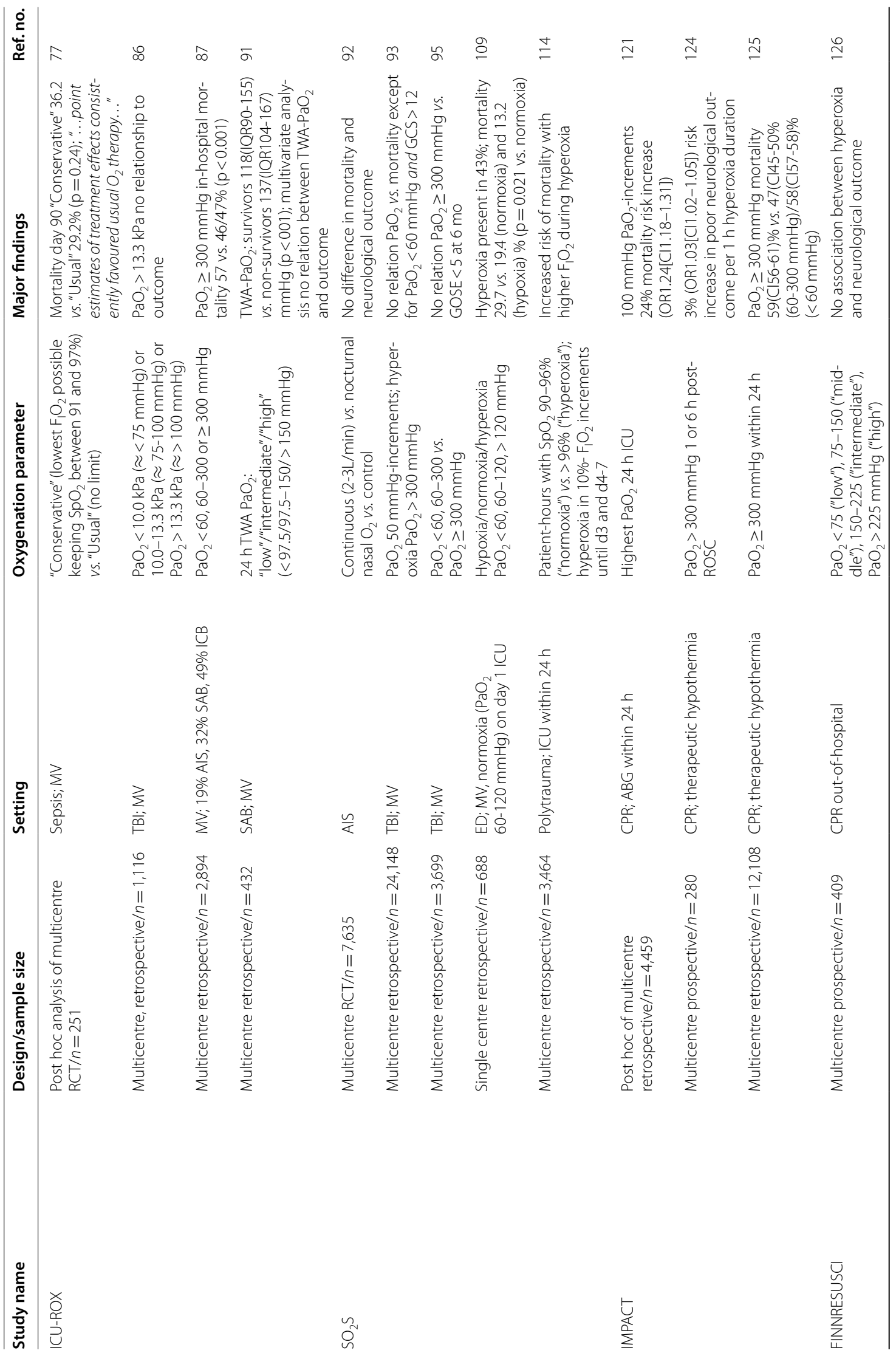



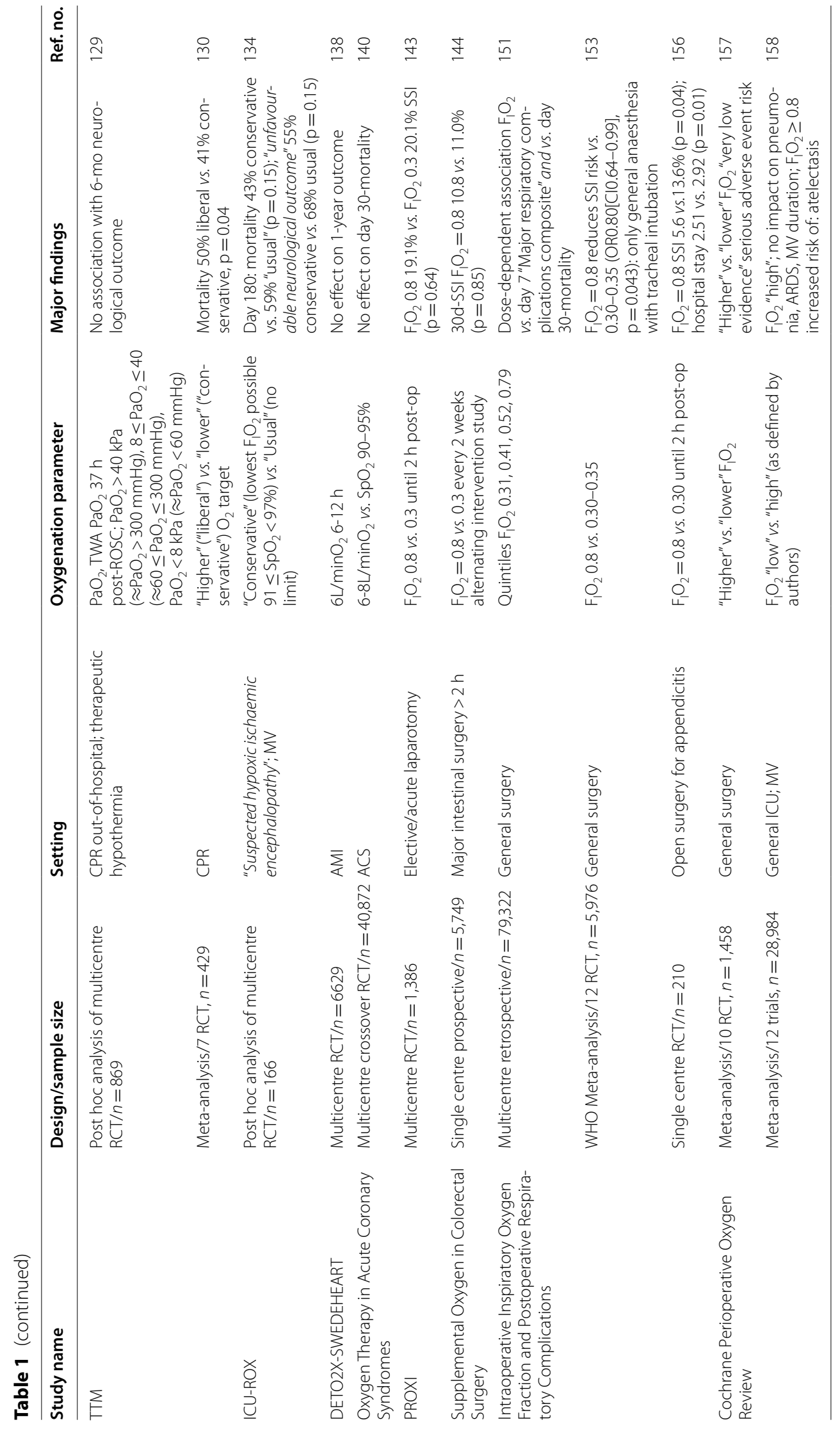
Neurotoxicity was described over a century ago [27]: $3 \mathrm{Atm}$ of $\mathrm{O}_{2}$ produced convulsions and death. Seizures or syncope occurred after $40 \mathrm{~min}$ at $4 \mathrm{Atm} \mathrm{O}_{2}$, and within $5 \mathrm{~min}$ at $7 \mathrm{Atm}$ [28]. This was usually preceded by milder symptoms such as tunnel vision, tinnitus, twitching, confusion, and vertigo. The impact of high concentration normobaric $\mathrm{O}_{2}$ on neurotoxicity, however, is unclear.

Mitochondrial ROS production increases either with $\mathrm{O}_{2}$ deficit or excess, but particularly during excess $\mathrm{O}_{2}$ (hyperoxia). This can occur in sepsis and/or I/R injury, i.e. whole-body (e.g. resuscitation from cardiac arrest or major haemorrhage), or organ-specific (e.g. revascularisation after myocardial infarction or stroke). A similar injury may be induced by acute hypoxaemia followed by rapid correction (hypoxia/re-oxygenation-injury). The impact of reperfusion injury may be as severe as the ischaemic insult. Although preclinical and clinical studies are not consistent [29-31], reperfusion injury is generally exacerbated by hyperoxia. The hyperoxia effect may be exacerbated by acidification of the hypoxic tissues; the right-shifted oxyhaemoglobin dissociation curve of blood (re-)entering the hypoxic tissue augments $\mathrm{O}_{2}$ release, with a subsequent increase in superoxide production [31].

Teleologically, the body has not evolved to deal with high tissue $\mathrm{O}_{2}$ tensions. Tissues not metabolising adequately, e.g. due to toxins or switching off ("hibernating") in response to hypoperfusion, reduce $\mathrm{O}_{2}$ utilisation. As a normal protective response, negative feedback signals reduce local blood flow by vasoconstriction to mitigate local build-up of $\mathrm{O}_{2}$ and subsequent toxicity. Acute hyperoxia thus induces vasoconstriction, reducing local blood flow [32], particularly in the cerebral and coronary vasculature [5-7]. This vasoconstriction is in part related to reduced release of nitric oxide (NO) from $S$-nitrosohaemoglobin binding [33]. Vasoconstriction has been shown in patients with and without coronary artery disease, where supplemental $\mathrm{O}_{2}$ reduced cardiac output and coronary sinus blood flow [34, 35]. Seizures associated with neurological $\mathrm{O}_{2}$ toxicity occur with paradoxical vasodilation during hyperbaric hyperoxia [6].

\section{General ICU patients}

The Oxygen-ICU trial was the first major study to suggest clinically important harm from liberal $\mathrm{O}_{2}$ administration in a general ICU population [36]. This single-centre, RCT included 480 patients expected to stay in the ICU for at least $72 \mathrm{~h}$. ICU mortality was $20.2 \%$ with conventional and $11.6 \%$ with conservative $\mathrm{O}_{2}$ therapy. Around twothirds of patients included were mechanically ventilated at baseline, around a third had shock, and the illness acuity was relatively low. The difference was statistically significant although the study was stopped early after a non-preplanned interim analysis, and the magnitude of the reported treatment effect was larger than hypothesised [36]. Given the variety of mechanisms of death in ICU patients [37], such a high proportion of deaths in a heterogeneous population of ICU patients is unlikely to be attributable to the dose of $\mathrm{O}_{2}$ therapy used. However, the Oxygen-ICU trial [37] did highlight the need for further investigation.

Subsequently, the IOTA systematic review and metaanalysis [38] reported that conservative $\mathrm{O}_{2}$ use in acutely ill adults significantly reduced in-hospital mortality. Although these findings were concordant with the Oxygen-ICU trial [36], they provided only low certainty evidence: First, the Oxygen-ICU trial [36] contributed 32\% of the weight to the mortality analysis. Second, predominant conditions were acute myocardial infarction and stroke, and a range of $\mathrm{O}_{2}$ regimens were tested so that the analysis provided only indirect evidence about the optimal $\mathrm{O}_{2}$ regimen for patients in the ICU. Third, the overall mortality treatment effect estimates were imprecise. Finally, an updated systematic review and meta-analysis found no evidence of benefit or harm comparing higher $v s$. lower oxygenation strategies in acutely ill adults [39].

The multicentre randomised ICU-ROX trial found that conservative $\mathrm{O}_{2}$ therapy did not significantly affect the primary end point of number of days alive and free from mechanical ventilation (ventilator-free days) compared with usual (liberal) $\mathrm{O}_{2}$ therapy [40]. Overall, 32.2\% of conservative and $29.7 \%$ of usual $\mathrm{O}_{2}$ patients died in hospital. While these findings provide some reassurance to clinicians about the safety of the liberal $\mathrm{O}_{2}$ use that occurs in standard practice, they do not exclude clinically important effects of the $\mathrm{O}_{2}$ regimens tested on mortality risk. Indeed, based on the distribution of data, there is a $46 \%$ chance that conservative $\mathrm{O}_{2}$ therapy increases absolute mortality by more than $1.5 \%$ points, and a $19 \%$ chance that conservative $\mathrm{O}_{2}$ therapy decreases absolute mortality by more than $1.5 \%$ points [41, 42]. Finally, a recent RCT conducted in ICU patients fulfilling the systemic inflammatory response syndrome criteria, found no significant difference between high-normal and lownormal oxygenation targets for non-respiratory organ dysfunction over the first 14 days, or in Day-90 mortality [43]. Accordingly, the most appropriate dose of $\mathrm{O}_{2}$ to give to adult ICU patients remains uncertain.

\section{ARDS}

Clinicians should titrate $\mathrm{O}_{2}$ therapy to avoid both hypoxaemia and hyperoxaemia. While the harmful effects of tissue hypoxia are clearly understood [44], overcorrection leads to tissue hyperoxia which may also be deleterious. Hyperoxia injures the lung via ROS production, causing oxidant stress with pro-inflammatory and 
cytotoxic effects $[35,45,46]$. Pathophysiologic consequences include arterial vasoconstriction [35, 47-49], alveolar-capillary "leak" and even fibrogenesis [50, 51]. Clinicians use higher $\mathrm{F}_{\mathrm{I}} \mathrm{O}_{2}$ than necessary to correct hypoxia in the critically ill [52], possibly to avoid (occult) tissue hypoxia [53, 54], to provide a "buffer" should rapid clinical deterioration occur, or because the consequences of hyperoxia are considered less severe. The lack of clearly defined targets for $\mathrm{PaO}_{2}$ and/or $\mathrm{SaO}_{2}$ is also an issue. The ARDS Network trials targeted a $\mathrm{PaO}_{2}$ of $55-80 \mathrm{mmHg}$ [55], while the British Thoracic Society suggests a target $\mathrm{SpO}_{2}$ of $94-98 \%$ in acutely ill patients [56].

In ARDS, the potential for hyperoxia to impact outcomes is further complicated by the severity of gas exchange impairment. Specifically, extreme hyperoxaemia (i.e. $\mathrm{PaO}_{2}>300 \mathrm{mmHg}$ ), associated with harm in other critically ill populations, is impossible to achieve in ARDS (see Table 1). However, moderate hyperoxaemia is possible and could be harmful as well [57]. Furthermore, high $\mathrm{F}_{\mathrm{I}} \mathrm{O}_{2}$ can directly injure the lung [58], sensitise it to subsequent injury [59], adversely affect its innate immune response [60], and worsen ventilation-induced injury [61, 62]. It is therefore necessary to distinguish between hyperoxaemia and high $\mathrm{F}_{\mathrm{I}} \mathrm{O}_{2}$ use when assessing the effects of hyperoxia on the lung.

The recent LOCO2 trial in ARDS was stopped early for futility and safety concerns regarding mesenteric ischaemia in the conservative $\mathrm{O}_{2}$ group. Moreover, 90-day mortality was significantly higher in patients receiving conservative $\mathrm{O}_{2}$ therapy [63]. The HOT-ICU trial studied ICU patients with acute hypoxaemic respiratory failure and found no difference in 90-day mortality between conservative and liberal $\mathrm{PaO}_{2}$ targets [64]. In the LUNG SAFE observational cohort study, both systemic hyperoxaemia and excess $\mathrm{F}_{\mathrm{I}} \mathrm{O}_{2}$ use were prevalent, with frank hyperoxaemia ( $30 \%$ of patients) more prevalent than hypoxaemia in early ARDS [65]. Two-thirds of these patients received excess $\mathrm{O}_{2}$ therapy. Hyperoxaemia did not appear to be used as a "buffer" in unstable patients: frequency was similar in shocked patients. While a similar proportion of patients were hyperoxaemic on day-2, higher $\mathrm{F}_{\mathrm{I}} \mathrm{O}_{2}$ use did decrease. Both hyperoxaemia and excess $\mathrm{O}_{2}$ use were mostly transient, although more sustained hyperoxaemia was seen. Reassuringly, no relationship was found between the degree and duration of hyperoxaemia, or excessive $\mathrm{O}_{2}$ use, and mortality in early ARDS.

While these findings contrast with findings in other ICU cohorts, a key differentiating factor is the reduced potential for extreme hyperoxia in ARDS patients. The potential for harm from hyperoxia appears to be related to the severity of hyperoxaemia [54, 61, 66, 67]; those with relatively preserved lung function are at greatest risk [68]. However, no dose-response relation was found between $\mathrm{PaO}_{2}$ and mortality [67]. Hence, paradoxically, patients with ARDS may be at less risk as they are unable to achieve extreme degrees of hyperoxia. A recent observational study suggested a U-shaped relationship between $\mathrm{PaO}_{2}$ and mortality in ARDS patients; patients with a time-weighted $\mathrm{PaO}_{2}$ of 93.8-105 mmHg had the lowest mortality risk [69]. Intriguingly, this range is near identical to the "liberal" target $\mathrm{PaO}_{2}$ range targeted in the LOCO2 [63]. Hence, much remains to be learned about optimal targeting of $\mathrm{PaO}_{2}$ in patients with ARDS.

\section{Sepsis and septic shock}

Theoretically, hyperox(aem)ia might help septic patients due to its vasoconstrictor effect, counteracting hypotension [6-8], and to the antibacterial effects of $\mathrm{O}_{2}[70$, 71]. However, hyperoxaemia did not affect cardiac output in septic patients [72]. The number of days with $\mathrm{PaO}_{2}>120 \mathrm{mmHg}$ was an independent risk factor for ventilator-associated pneumonia (VAP) [73]; however, these patients had other risk factors, e.g. more frequent use of proton pump inhibitors and sedatives, higher incidence of circulatory shock with prolonged and higher catecholamine infusion rates, and more red blood cell transfusion. In an observational study on VAP patients, the same group reported that hyperoxaemia did not affect mortality [74]. The HYPER2S RCT [75] compared standard therapy vs. $100 \% \mathrm{O}_{2}$ over the first $24 \mathrm{~h}$ after diagnosing septic shock. Despite a significantly lower SOFA score at day 7, the trial was prematurely stopped due to higher, albeit not statistically significant mortality in the hyperoxia group at Day-28 and Day-90. The hyperoxia group had significantly more serious adverse events, including ICU-acquired weakness $(p=0.06)$. A post hoc analysis based on Sepsis-3 criteria found increased Day-28 mortality in patients with hyperlactataemia $>2 \mathrm{mmol} / \mathrm{L}$ $(p=0.054)$, but not with normal lactate levels [76]. The authors speculated that a hyperoxaemia-related increase in tissue $\mathrm{O}_{2}$ availability may have led to excess ROS production and, consequently, oxidative stress-related tissue damage.

The opposite hypothesis, i.e. attenuation of oxidative stress-induced tissue damage by reducing $\mathrm{O}_{2}$ exposure did not beneficially influence outcome in septic patients either. A post hoc analysis of the ICU-ROX trial [40] of the septic cohort showed no statistically significant difference with respect to ventilator-free days or Day-90 mortality for the "conservative" when compared to the "usual" oxygenation [77]. Point estimates of treatment effects even favoured the latter. Hence, it seems reasonable to avoid $\mathrm{PaO}_{2}>100-120 \mathrm{mmHg}$ due to the possible deleterious consequences of excess tissue $\mathrm{O}_{2}$ 
concentrations in the presence of sepsis-related impairments of cellular $\mathrm{O}_{2}$ extraction [78].

\section{Acute brain injury}

Increasing $\mathrm{F}_{\mathrm{I}} \mathrm{O}_{2}$ in acutely brain-injured patients, alongside other clinical interventions [79], can improve brain tissue $\mathrm{PO}_{2}\left(\mathrm{PbtO}_{2}\right)[80,81]$. The effects of normobaric hyperoxia are less significant in large hypoperfused brain regions [82], but highly relevant in small pericontusional areas [83]. Moreover, incremental $\mathrm{F}_{\mathrm{I}} \mathrm{O}_{2}$ increased cerebral excitotoxicity in severe traumatic brain injury (TBI) [84]. The association of hyperoxia with outcome is even more controversial. After TBI, both hypoxaemia and hyperoxia were [85] or were not [86] independently associated with worse outcome. In two retrospective studies, including a mixed population of brain-injured patients, hyperoxaemia, defined as $\mathrm{PaO}_{2}>300 \mathrm{mmHg}$ [87] or $>120 \mathrm{mmHg}$ [88], was associated with increased in-hospital mortality and poor neurological outcome, even after adjusting for confounders. Patients with subarachnoid haemorrhage exposed to higher $\mathrm{PaO}_{2}$ levels were also more likely to develop cerebral vasospasm [89, 90]; however, a retrospective analysis of patients needing mechanically ventilation did not find any relation between time-weighted $\mathrm{PaO}_{2}$ and outcome [91]. Studies in acute ischaemic stroke in general [92], and in a sub-group needing mechanical ventilation [93], found no association between outcome and $\mathrm{PaO}_{2}$ within the first $24 \mathrm{~h}$. Even early hyperoxaemia $\left(\mathrm{PaO}_{2}>300 \mathrm{mmHg}\right)$ did not affect mortality in mechanically ventilated TBI patients, notwithstanding severity on admission [94, 95]. Finally, $\mathrm{PaO}_{2} \approx 150-250 \mathrm{mmHg}$ within the first $24 \mathrm{~h}$ post-TBI was associated with better longterm functional outcome after TBI [96]; however, the study excluded patient who died. Normobaric hyperoxia combined with intravenous thrombolysis was associated with more favourable neurological outcome than thrombolysis alone after ischaemic stroke [97].

Prospective studies have evaluated the effects of targeted hyperoxia after acute brain injury: Small studies in patients with acute ischaemic stroke not eligible for thrombolysis found either transient clinical improvement and smaller infarct size with high-flow $\mathrm{O}_{2}[98,99]$ or no effect of normobaric hyperoxia [100]. In a small RCT in mechanically ventilated TBI patients, $\mathrm{F}_{\mathrm{I}} \mathrm{O}_{2}=0.8$ (vs. 0.5) improved 6-month neurological outcome [101], but conclusions should be cautioned due to methodological concerns. Exposure to $\mathrm{F}_{\mathrm{I}} \mathrm{O}_{2}=0.7$ or 0.4 for up to 14 days after TBI influenced neither markers of oxidative stress or inflammation nor neurological outcome [102]. Finally, the Normobaric-Oxygen-Therapy-in-AcuteIschemic-Stroke-Trial (NCT00414726) was prematurely halted after inclusion of $85 / 240$ patients because of higher mortality in the high-flow $\mathrm{O}_{2}$ group, although most deaths occurred following early withdrawal of life-support.

It remains open in acute brain injury, whether normoxaemia $v s$. targeted hyperoxaemia influences brain function and neurological recovery. Optimal $\mathrm{PaO}_{2}$ targets, study populations, and specific forms of brain injury are currently unknown.

\section{Trauma-and-haemorrhage}

Supplemental $\mathrm{O}_{2}$ is used because increasing the amount of physically dissolved $\mathrm{O}_{2}$ during blood loss-related reductions in $\mathrm{O}_{2}$ transport is thought to faster repay a tissue $\mathrm{O}_{2}$ debt [103]. Despite its vasoconstrictor properties [6-8], ventilation with $100 \% \mathrm{O}_{2}$ during experimental haemorrhage improved tissue $\mathrm{PO}_{2}[104]$ and attenuated organ dysfunction $[105,106]$.

However, $\mathrm{PaO}_{2}>100 \mathrm{mmHg}$ may enhance ROS formation [9-11], especially during $\mathrm{I} / \mathrm{R}$ and/or hypoxia/ re-oxygenation, e.g. resuscitation from trauma-andhaemorrhage [6-8].

A recent retrospective study in patients with prehospital emergency anaesthesia demonstrated that hyperoxia was present in most patients upon arrival in the hospital, however without relation to outcome [107]. Clinical data on the impact of hyperoxia on morbidity and mortality remain equivocal. No association was seen between mortality and $\mathrm{PaO}_{2}$ in the first $24 \mathrm{~h}$ (median Injury Severity Score ISS =29) [108]. Another observational study noted that $44.5 \%$ of patients mechanically ventilated in the emergency department had hyperoxaemia, this cohort having a higher Day-28 mortality [109]. From a French trauma registry (median ISS $=16$ ), univariate analysis showed that admission $\mathrm{PaO}_{2}>150 \mathrm{mmHg}$ coincided with a higher mortality, however, propensity score matching yielded the opposite result, namely supra-physiological $\mathrm{PaO}_{2}$ levels were associated with significantly lower mortality [110]. Lower Day-28 mortality and less nosocomial pneumonia were seen in patients early after blunt chest trauma [111]. An analysis of 864,340 trauma patients (median ISS =9) investigated the impact of supplemental $\mathrm{O}_{2}$ in the ED; in all three patient categories predefined according to incremental $\mathrm{SpO}_{2}$, supplemental $\mathrm{O}_{2}$ was associated with a significantly higher ARDS incidence and mortality [112]. A retrospective analysis of patients with ISS $\geq 16$ studied the impact of $\mathrm{PaO}_{2} \geq 300 \mathrm{mmHg}$ during resuscitation [113]; while prolonged ICU stay was seen in patients not intubated in the ED, no effect was seen in the sicker cohort of mechanically ventilated patients. Finally, a retrospective multicentre study of trauma patients found $\mathrm{SpO}_{2}>96 \%$ over the first seven days was common place; the adjusted mortality risk was higher with greater $\mathrm{F}_{\mathrm{I}} \mathrm{O}_{2}$ [114]. The currently recruiting 
"Strategy-to-Avoid-Excessive-Oxygen-for-CriticallyIll-Trauma-Patients (SAVE-O2)" (NCT04534959) will address any causality between hyperoxia and outcome.

Despite $\mathrm{O}_{2}$ supplementation being common practice in patients with pronounced blood loss, no optimal target for $\mathrm{PaO}_{2}$ is available.

\section{Cardiopulmonary resuscitation and myocardial infarction}

During cardiac arrest, $\mathrm{PbtO}_{2}$ drops rapidly to levels close to zero [115]. With cardiopulmonary resuscitation (CPR) $\mathrm{PbtO}_{2}$ increases slowly, driven by the achieved cerebral perfusion pressure [116]. Guidelines recommend ventilation with $100 \% \mathrm{O}_{2}$ even though no clinical study has compared this against lower $\mathrm{F}_{\mathrm{I}} \mathrm{O}_{2}$ [117]. Observational data suggest an association between higher $\mathrm{PaO}_{2}$ during $\mathrm{CPR}$ and a higher likelihood of return of spontaneous circulation (ROSC), survival, and neurological outcome [118, 119]. After ROSC blood and brain $\mathrm{PO}_{2}$ levels increase; mostly, this appears inevitable as $\mathrm{F}_{\mathrm{I}} \mathrm{O}_{2}$ titration is impossible during CPR [120]. Given the connection between hyperoxia and ROS formation, there has been great interest in assessing whether avoidance of hyperoxaemia in the post-arrest phase could mitigate brain injury. Results are conflicting, either showing an association between hyperoxia and poor outcome [68, 121-124], or not [125-129]. Smaller randomised trials and sub-group analysis from larger trials have also been performed [130]. Overall, the evidence suggests that lower rather than higher $\mathrm{O}_{2}$ targets are beneficial, even though any sweet spot for optimal $\mathrm{PaO}_{2}$ is unknown [131]. The COMACARE pilot trial compared different $\mathrm{PaO}_{2}$ targets and found no difference in two brain injury biomarkers $[132,133]$. A sub-group analysis of the ICU-ROX study showed improved outcomes in restrictive compared to liberal $\mathrm{O}_{2}$ treated patients at risk of hypoxic brain injury [134]. Opposite findings were seen in a sub-group of the HOT-ICU trial [64]. Current guidelines recommend targeting strict normox(aem)ia. The evidence suggests a signal to harm and, importantly, no indication of benefit from extreme hyperox(aem)ia; thus, this should be avoided [135].

Supplemental $\mathrm{O}_{2}$ use has been standard practice for decades in acute myocardial infarction (AMI) [136]. Studies have nonetheless suggested side effects including coronary artery vasoconstriction [137]. Several large studies have shown either harm or lack of benefit from supplemental $\mathrm{O}_{2}$ use in patients without hypoxaemia [138, 139]. A large cluster randomised controlled trial of $>40,000$ patients with acute coronary syndrome (including patients with AMI) found no benefit with supplemental $\mathrm{O}_{2}$ use overall, but evidence was inconclusive in patients with ST-elevation AMI [140]. Importantly, these trials included patients without hypoxaemia [138, 140]. Despite the lack of high-quality evidence, it appears prudent to avoid hypoxaemia $\left(\mathrm{SaO}_{2}<90 \%\right)$ in AMI patients.

\section{Perioperative hyperoxia}

Trials of intraoperative hyperoxia have mainly been performed in elective surgery to prevent surgical wound infection through increased tissue oxygenation [141, 142]. Initial enthusiasm was followed by larger trials with similar wound complication frequencies with $\mathrm{F}_{\mathrm{i}} \mathrm{O}_{2}=0.80$ vs. 0.30 perioperatively $[143,144]$. Concerns have been raised by shorter cancer-free survival in patients given $\mathrm{F}_{\mathrm{i}} \mathrm{O}_{2}=0.80[145,146]$. A higher $\mathrm{F}_{\mathrm{I}} \mathrm{O}_{2}$ is used to ensure adequate or, in some cases, supranormal end-organ oxygenation, although there is sparse evidence of benefit.

Both preoxygenation and high intraoperative $\mathrm{F}_{\mathrm{I}} \mathrm{O}_{2}$ can cause resorption atelectasis [147], especially in patients with pulmonary comorbidity, as general anaesthesia itself reduces functional residual capacity and causes airway closure [148]. As ventilation-perfusion mismatch and shunt contribute to impaired oxygenation, use of $\mathrm{F}_{\mathrm{I}} \mathrm{O}_{2}=0.30-0.35$ is therefore considered normal during general anaesthesia $[149,150] . \mathrm{F}_{\mathrm{I}} \mathrm{O}_{2} \geq 0.80$ caused significant atelectasis during preoxygenation, but this can be eliminated with a recruitment manoeuvre followed by $5-10 \mathrm{cmH}_{2} \mathrm{O}$ PEEP [14], which clearly is not common practice. Failure to correct such iatrogenic atelectasis may trigger the use of excessive perioperative $\mathrm{F}_{\mathrm{I}} \mathrm{O}_{2}$. In a large observational study [151], high intraoperative $\mathrm{F}_{\mathrm{I}} \mathrm{O}_{2}$ was dose-dependently associated with major pulmonary complications and mortality after adjustment for all relevant risk factors. This association has not yet been confirmed in RCTs [152].

Based on a sub-group analysis in a systematic review, the World Health Organization proposed using $\mathrm{F}_{\mathrm{I}} \mathrm{O}_{2}=0.80$ in all intubated patients to prevent postoperative wound infections [153]. This engendered controversial discussion [154, 155]. Most of the evidence for risks and benefits of hyperoxia during emergency surgery arise from RCTs of 385 laparotomy procedures and 210 open appendicectomies [143, 156]. While wound infections were significantly reduced with $\mathrm{F}_{\mathrm{I}} \mathrm{O}_{2}=0.80$ in the appendicectomy study, the frequencies of surgical site infections, serious adverse events and mortality did not differ in the laparotomy trial $[156,157]$.

Acute perioperative patients should be carefully treated with respect to their ongoing medical conditions; most current evidence suggests greatest safety with $\mathrm{O}_{2}$ titration to normoxaemia. 


\section{Conclusions}

Current evidence suggests that $\mathrm{PaO}_{2}>300 \mathrm{mmmHg}$ should be avoided in most ICU patients. It remains uncertain whether there is a "sweet spot" $\mathrm{PaO}_{2}$ target, which may vary for given clinical conditions. Systematic reviews using trial sequential analysis to take into account high $v s$. low bias risk found no effect (including all patients [39]) or increased mortality (including only ICU patients [157]) from higher oxygenation targets. Certainty evidence was low with futility for a $15 \%$ relative mortality risk increase. The currently recruiting "MegaRandomised-Registry-Trial-Comparing-Conservative-vs.Liberal-Oxygenation (Mega-ROX trial)" (CTG1920-01) in 40,000 patients should provide any "ideal target $\mathrm{PaO}_{2}$ ": The trial tests the hypothesis that conservative $v s$. liberal $\mathrm{O}_{2}$ targets reduce mortality by $1.5 \%$ points in mechanically ventilated, adult ICU patients, i.e. 1,500 lives saved for every 100,000 patients treated. Since both conservative and liberal $\mathrm{O}_{2}$ therapy may be best for certain patients, several parallel trials will evaluate pre-specified hypotheses in specific patient cohort patients accompanied by separate power calculations. For example, anticipating heterogeneity of treatment response, in septic patients or patients with acute brain pathologies (other than hypoxic brain injuries), the trial will test the opposite hypothesis that liberal (rather than conservative) $\mathrm{O}_{2}$ will reduce mortality. Finally, the trial design cannot exclude that for some patient sub-groups, a different window of $\mathrm{O}_{2}$ exposure is most suited.

So far, it appears prudent to target $\mathrm{PaO}_{2}$ values within the normal range, i.e. carefully titrating $\mathrm{PaO}_{2}$ to avoid both hypoxaemia and excess hyperoxaemia [158], particular as no clinically useful biomarker of $\mathrm{O}_{2}$ toxicity is available, and data on the effects of hyperoxia on markers of oxidative stress are equivocal [10, 159-161].

\section{Supplementary Information}

The online version contains supplementary material available at https://doi. org/10.1186/s13054-021-03815-y.

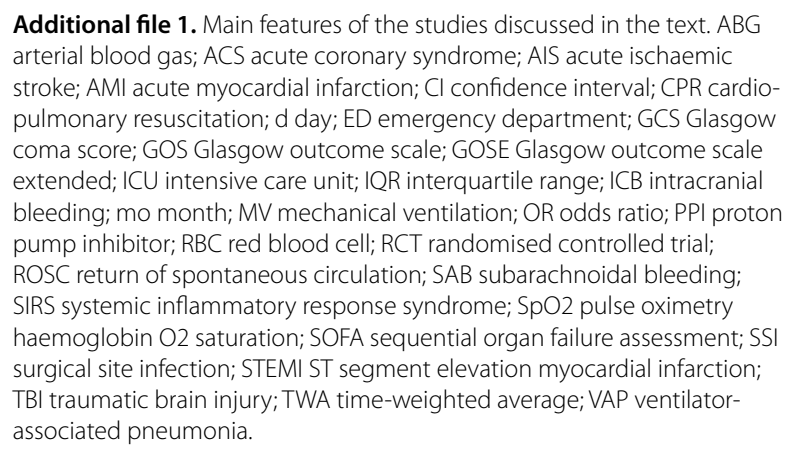

Acknowledgements

Not applicable.

\section{Authors' contributions}

M. Singer contributed to subchapter on pathophysiology; PJY contributed to subchapter on general ICU population; JGL contributed to subchapter on ARDS; PA contributed to subchapter on sepsis and septic shock; FST contributed to subchapter on acute brain injury; PR contributed to subchapter on trauma-and-haemorrhage; M. Skrifvars contributed to subchapter on CPR and $\mathrm{Ml}$; CSM contributed to subchapter on perioperative hyperoxia. All authors read and approved the final manuscript.

\section{Funding}

Open Access funding enabled and organized by Projekt DEAL. PR was supported by the Deutsche Forschungsgemeinschaft (DFG, German Research Foundation), Project-ID 251293561, CRC 1149. This research was conducted during the tenure of a Health Research Council of New Zealand Clinical Practitioner Research Fellowship held by PY. The Medical Research Institute of New Zealand is supported by independent research organisation funding from the Health Research Council of New Zealand.

\section{Availability of data materials}

Not applicable.

\section{Declarations}

Ethical approval and consent to participate

Not applicable.

\section{Consent for publication}

Not applicable.

\section{Competing interests}

The authors declare that they have no competing interests..

\section{Author details}

${ }^{1}$ Bloomsbury Institute of Intensive Care Medicine, Division of Medicine, University College London, London, UK. ${ }^{2}$ Medical Research Institute of New Zealand, and Intensive Care Unit, Wellington Hospital, Wellington, Wellington, New Zealand. ${ }^{3}$ Australian and New Zealand Intensive Care Research Centre, Department of Critical Care Medicine, University of Melbourne, Melbourne, VIC, Australia. ${ }^{4}$ Department of Anaesthesia and Intensive Care Medicine, Galway University Hospitals, and School of Medicine, National University of Ireland, Galway, Ireland. ${ }^{5}$ Département de Médecine Intensive - Réanimation Et Médecine Hyperbare, Centre Hospitalier Universitaire d'Angers, Angers, France. ${ }^{6}$ Department of Intensive Care, Hôpital Erasme, Université Libre de Bruxelles, Bruxelles, Belgium. ${ }^{7}$ Department of Emergency Care and Services, University of Helsinki and Helsinki University Hospital, Helsinki, Finland. ${ }^{8}$ Department of Anaesthesia and Intensive Care, Bispebjerg and Frederiksberg Hospital, University of Copenhagen, Copenhagen, Denmark. ${ }^{9}$ Institut für Anästhesiologische Pathophysiologie und Verfahrensentwicklung, Universitätsklinikum, Helmholtzstrasse 8-1, 89081 Ulm, Germany.

Received: 20 August 2021 Accepted: 4 November 2021

Published online: 19 December 2021

\section{References:}

1. West JB. Carl Wilhelm Scheele, the discoverer of oxygen, and a very productive chemist. Am J Physiol Lung Cell Mol Physiol. 2014;307(11):L811-6.

2. West JB. Joseph Priestley, oxygen, and the enlightenment. Am J Physiol Lung Cell Mol Physiol. 2014;306(2):L111-9.

3. West JB. The collaboration of Antoine and Marie-Anne Lavoisier and the first measurements of human oxygen consumption. Am J Physiol Lung Cell Mol Physiol. 2013;305(11):L775-85. 
4. Leverve XM. To cope with oxygen: a long and still tumultuous story for life. Crit Care Med. 2008;36(2):637-8.

5. Asfar $\mathrm{P}$, Singer $\mathrm{M}$, Radermacher P. Understanding the benefits and harms of oxygen therapy. Intensive Care Med. 2015;41 (6):1118-21.

6. Hafner S, Beloncle F, Koch A, Radermacher P, Asfar P. Hyperoxia in intensive care, emergency, and peri-operative medicine: Dr. Jekyll or Mr. Hyde? A 2015 update. Ann Intensive Care. 2015;5(1):42.

7. Demiselle J, Calzia E, Hartmann C, Messerer DAC, Asfar P, Radermacher $\mathrm{P}$, Datzmann T. Target arterial $\mathrm{PO}_{2}$ according to the underlying pathology: a mini-review of the available clinical data. Ann Intensive Care. 2021;11(1):88.

8. Turrens J. Mitochondrial formation of reactive oxygen species. J Physiol. 2003:552(Pt 2):335-44.

9. Jamieson D, Chance B, Cadenas E, Boveris A. The relation of free radical production to hyperoxia. Annu Rev Physiol. 1986;48:703-19.

10. Khaw KS, Wang CC, Ngan Kee WD, Pang CP, Rogers MS. Effects of high inspired oxygen fraction during elective caesarean section under spinal anaesthesia on maternal and fetal oxygenation and lipid peroxidation. Br J Anaesth. 2002;88(1):18-23.

11. Hafner C, Pramhas S, Schaubmayr W, Assinger A, Gleiss A, Tretter EV, Klein KU, Schrabert G. Brief high oxygen concentration induces oxidative stress in leukocytes and platelets - a randomised cross-over pilot study in healthy male volunteers. Shock. 2021. https://doi.org/10.1097/ SHK.0000000000001728.

12. Magder S. Reactive oxygen species: toxic molecules or spark of life? Crit Care. 2006;10(1):208.

13. Warren CPW. The introduction of oxygen for pneumonia as seen through the writings of two McGill University professors, William Osler and Jonathan Meakins. Can Respir J. 2005;12(2):81-5.

14. Clark JM, Lambertsen CJ. Pulmonary oxygen toxicity: a review. Pharmacol Rev. 1971:23(2):37-133.

15. Hochberg $\mathrm{CH}$, Semler MW, Brower RG. Oxygen toxicity in critically ill adults. Am J Respir Crit Care Med. 2021;204(6):632-41.

16. Rhee SG. Cell signalling. $\mathrm{H}_{2} \mathrm{O}_{2}$, a necessary evil for cell signaling. Science. 312(5782):1882-3.

17. Sjöberg F, Singer M. The medical use of oxygen: a time for critical reappraisal. J Intern Med. 274(6):505-28.

18. Smith JL. The pathological effects due to increase of oxygen tension in the air breathed. J Physiol. 1899;24(1):19-35.

19. Jackson RM. Pulmonary oxygen toxicity. Chest. 1985;88(6):900-5.

20. Robinson FR, Casey HW. Weibel .Animal model: Oxygen toxicity in nonhuman primates. Am J Pathol. 1974:76(1):175-8.

21. Fracica PJ, Knapp MJ, Piantadosi CA, Takeda K, Fulkerson WJ, Coleman RE, Wolfe WG, Crapo JD. Responses of baboons to prolonged hyperoxia: physiology and qualitative pathology. J Appl Physiol. 1991;71(6):2352-62.

22. Crapo JD, Hayatdavoudi G, Knapp MJ, Fracica PJ, Wolfe WG, Piantadosi CA. Progressive alveolar septal injury in primates exposed to $60 \%$ oxygen for 14 days. Am J Physiol. 1994;267(6 Pt 1):L797-806.

23. Calzia E, Asfar P, Hauser B, Matejovic M, Ballestra C, Radermacher P, Georgieff M. Hyperoxia may be beneficial. Crit Care Med. 2010;38(10 Suppl):S559-68.

24. Dantzker DR, Wagner PD, West JB. Instability of lung units with low VA/Q ratio during O2 breathing. J Appl Physiol. 1975;38(5):886-95.

25. Demchenko IT, Welty-Wolf KE, Allen BW, Piantadosi CA. Similar but not the same: normobaric and hyperbaric pulmonary oxygen toxicity, the role of nitric oxide. Am J Physiol Lung Cell Mol Physiol. 2007;293(1):L229-38.

26. Tryka AF, Godleski JJ, Brain JD. Differences in effects of immediate and delayed hyperoxia exposure on bleomycin-induced pulmonic injury. Cancer Treat Rep. 1984;68(5):759-64.

27. Bert PL. Pression Barométrique: Recherches de Physiologie Expérimentale. Paris: G. Masson; 1878.

28. Behnke AR, Johnson FS, Poppen JR, Motley EP. The effect of oxygen on man at pressures from 1 to 4 atmospheres. Am J Physiol. 1934:110:565-72.

29. Ellman PI, Alvis JS, Tache-Leon C, Singh R, Reece TB, Kern JA, Tribble CG, Kron IL. Hyperoxic ventilation exacerbates lung reperfusion injury. J Thorac Cardiovasc Surg. 2005;130:1440.
30. Mariero LH, Rutkovskiy A, Stensløkken KO, Vaage J. Hyperoxia during early reperfusion does not increase ischemia/reperfusion injury. Eur J Cardiothorac Surg. 2012;41:149-53.

31. Wolbarsht ML, Fridovich I. Hyperoxia during reperfusion is a factor in reperfusion injury. Free Radic Biol Med. 1989;6:61-2.

32. Tsai A, Cabrales P, Winslow R, Intaglietta M. Microvascular oxygen distribution in the awake hamster window chamber model during hyperoxia. Am J Physiol Heart Circ Physiol. 2003;285:H1537-45.

33. Stamler JS, Jia L, Eu JP, McMahon TJ, Demchenko IT, Bonaventura J, Gernert K, Piantadosi CA. Blood flow regulation by S-nitrosohemoglobin in the physiological oxygen gradient. Science. 1997;276(5321):2034-7.

34. Ganz W, Donoso R, Marcus H, Swan HJ. Coronary hemodynamics and myocardial oxygen metabolism during oxygen breathing in patients with and without coronary artery disease. Circulation. 1972;45:763-8.

35. McNulty PH, Robertson BJ, Tulli MA, Hess J, Harach LA, Scott S, Sinoway LI. Effect of hyperoxia and vitamin C on coronary blood flow in patients with ischemic heart disease. J Appl Physiol. 2007;102(5):2040-5.

36. Girardis M, Busani S, Damiani E, Donati A, Rinaldi L, Marudi A, Morelli A, Antonelli M, Singer M. Effect of conservative vs conventional oxygen therapy on mortality among patients in an intensive care unit: the Oxygen-ICU randomized clinical trial. JAMA. 2016;316(15):1583-9.

37. Ridgeon E, Bellomo R, Myburgh J, Saxena M, Weatherall M, Jahan R, Arawwawala D, Bell S, Butt W, Camsooksai J, Carle C, Cheng A, Cirstea E, Cohen J, Cranshaw J, Delaney A, Eastwood G, Eliott S, Franke U, Gantner D, Green C, Howard-Griffin R, Inskip D, Litton E, Maclsaac C, McCairn A, Mahambrey T, Moondi P, Newby L, O'Connor S, Pegg C, Pope A, Reschreiter H, Richards B, Robertson M, Rodgers H, Shehabi Y, Smith I, Smith J, Smith N, Tilsley A, Whitehead C, Willett E, Wong K, Woodford C, Wright S, Young P. Validation of a classification system for causes of death in critical care: an assessment of inter-rater reliability. Crit Care Resusc. 2016:8(1):50-4.

38. Chu DK, Kim LH, Young PJ, Zamiri N, Almenawer SA, Jaeschke R, SzczeklikW, Schunemann HJ, Neary JD, Alhazzani W. Mortality and morbidity in acutely ill adults treated with liberal versus conservative oxygen therapy (IOTA): a systematic review and meta-analysis. Lancet. 2018;391(10131):1693-705.

39. Barbateskovic M, Schjørring OL, Krauss SR, Meyhoff CS, Jakobsen JC, B Rasmussen BS, Perner A, Jørn Wetterslev J. Higher vs lower oxygenation strategies in acutely ill adults: a systematic review with meta-analysis and trial sequential analysis. Chest. 2021;159(1):154-73.

40. ICU-ROX Investigators and the Australian and New Zealand Intensive Care Society Clinical Trials Group, Mackle D, Bellomo R, Bailey M, Beasley R, Deane A, Eastwood G, Finfer S, Freebairn R, King V, Linke N, Litton E, McArthur C, McGuinness S, Panwar R, Young P; ICU-ROX investigators the Australian and New Zealand Intensive Care Society Clinical Trials Group. Conservative oxygen therapy during mechanical ventilation in the ICU. N Engl J Med. 2020 Mar 12;382(11):989-98.

41. Young PJ, Bagshaw SM, Bailey M, Bellomo R, Mackle D, Pilcher D, Landoni G, Nichol A, Martin D. $\mathrm{O}_{2}$, do we know what to do? Crit Care Resusc. 2019;21(4):230-2.

42. Young PJ, Bellomo R. The risk of hyperoxemia in ICU patients: much ado about $\mathrm{O}_{2}$. Am J Respir Crit Care Med. 2019;200(11):1333-5.

43. Gelissen H, de Grooth HJ, Smulders Y, Wils EJ, de Ruijter W, Vink R, Smit B, Röttgering J, Atmowihardjo L, Girbes A, Elbers P, Tuinman PR, Oudemans-van Straaten H, de Man A. Effect of low-normal vs high-normal oxygenation targets on organ dysfunction in critically ill patients: a randomized clinical trial. JAMA. 2021;326(10):940-8.

44. MacIntyre NR. Tissue hypoxia: implications for the respiratory clinician. Respir Care. 2014;59(10):1590-6.

45. Brueckl C, Kaestle S, Kerem A, Habazettl H, Krombach F, Kuppe H, Kuebler WM. Hyperoxia-induced reactive oxygen species formation in pulmonary capillary endothelial cells in situ. Am J Respir Cell Mol Biol. 2006;34(4):453-63.

46. Mantell LL, Lee PJ. Signal transduction pathways in hyperoxia-induced lung cell death. Mol Genet Metab. 2000;71(1-2):359-70.

47. Bak Z, Sjöberg F, Rousseau A, Steinvall I, Janerot-Sjoberg B. Human cardiovascular dose-response to supplemental oxygen. Acta Physiol (Oxf). 2007:191(1):15-24.

48. Mak S, Egri Z, Tanna G, Coleman R, Newton GE. Vitamin C prevents hyperoxia-mediated vasoconstriction and impairment of 
endothelium dependent vasodilation. Am J Physiol Heart Circ Physiol. 2002;282:H2414-21.

49. Reinhart K, Spies CD, Meier-Hellmann A, Bredle DL, Hannemann L, Specht M, Schaffartzik W. N-acetylcysteine preserves oxygen consumption and gastric mucosal $\mathrm{pH}$ during hyperoxic ventilation. Am J Respir Crit Care Med. 1995;151(3 Pt 1):773-9.

50. Davis WB, Rennard SI, Bitterman PB, Crystal RG. Pulmonary oxygen toxicity. Early reversible changes in human alveolar structures induced by hyperoxia. N Engl J Med. 1983;309(15):878-83.

51. Kapanci Y, Tosco R, Eggermann J, Gould VE. Oxygen pneumonitis in man. Light- and electron-microscopic morphometric studies Chest. 1972;62(2):162-9.

52. Itagaki T, Nakano Y, Okuda N, Izawa M, Onodera M, Imanaka H, Nishimura M. Hyperoxemia in mechanically ventilated, critically ill subjects: incidence and related factors. Respir Care. 2015;60(3):335-40.

53. de Graaff AE, Dongelmans DA, Binnekade JM, de Jonge E. Clinicians' response to hyperoxia in ventilated patients in a Dutch ICU depends on the level of $\mathrm{FiO}_{2}$. Intensive Care Med. 2011;37(1):46-51.

54. Helmerhorst HJF, Arts DL, Schultz MJ, van der Voort PHJ, Abu-Hanna A,

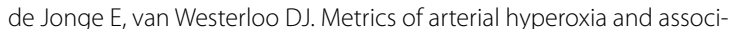
ated outcomes in critical care. Crit Care Med. 2017;45(2):187-95.

55. Network TARDS. Ventilation with lower tidal volumes as compared with traditional tidal volumes for acute lung injury and the Acute Respiratory Distress Syndrome. N Engl J Med. 2000;342(18):1301-8.

56. O'Driscoll BR, Howard LS, Earis J, Mak V, British Thoracic Society Emergency Oxygen Guideline G, Group BTSEOGD. BTS guideline for oxygen use in adults in healthcare and emergency settings. Thorax. 2017;72(Suppl 1):ii1-iig0.

57. Aggarwal NR, Brower RG, Hager DN, Thompson BT, Netzer G, Shanholtz C, Lagakos A, Checkley W, National Institutes of Health Acute Respiratory Distress Syndrome Network Investigators. Oxygen exposure resulting in arterial oxygen tensions above the protocol goal was associated with worse clinical outcomes in Acute Respiratory Distress Syndrome. Crit Care Med. 2018;46(4):517-24.

58. Yamada M, Kubo H, Kobayashi S, Ishizawa K, Sasaki H. Interferon-ү: a key contributor to hyperoxia-induced lung injury in mice. Am J Physiol Lung Cell Mol Physiol. 2004;287(5):L1042-7.

59. Aggarwal NR, D'Alessio FR, Tsushima K, Files DC, Damarla M, Sidhaye VK, Fraig MM, Polotsky VY, King LS. Moderate oxygen augments lipopolysaccharide-induced lung injury in mice. Am J Physiol Lung Cell Mol Physiol. 2010;298(3):L371-81.

60. Baleeiro CE, Wilcoxen SE, Morris SB, Standiford TJ, Paine R. Sublethal hyperoxia impairs pulmonary innate immunity. J Immunol. 2003;171(2):955-63.

61. Helmerhorst HJF, Schouten LRA, Wagenaar GTM, Juffermans NP, Roelofs $J$, Schultz MJ, de Jonge E, van Westerloo D. Hyperoxia provokes a time- and dose-dependent inflammatory response in mechanically ventilated mice, irrespective of tidal volumes. Intensive Care Med Exp. 2017;5(1):27.

62. Li LF, Liao SK, Ko YS, Lee CH, Quinn DA. Hyperoxia increases ventilatorinduced lung injury via mitogen-activated protein kinases: a prospective, controlled animal experiment. Crit Care. 2007;11(1):R25.

63. Barrot L, Asfar P, Mauny F, Winiszewski H, Montini F, Badie J, Quenot JP, Pili-Floury S, Bouhemad B, Louis G, Souweine B, Collange O, Pottecher J, Levy B, Puyraveau M, Vettoretti L, Constantin JM, Capellier G, LOCO2 Investigators and REVA Research Network. Liberal or conservative oxygen therapy for Acute Respiratory Distress Syndrome. N Engl J Med. 2020;382(11):999-1008.

64. Schjørring OL, Klitgaard TL, Perner A, Wetterslev J, Lange T, Siegemund M, Bäcklund M, Keus F, Laake JH, Morgan M, Thormar KM, Rosborg SA, Bisgaard J, Erntgaard AES, Lynnerup AH, Pedersen RL, Crescioli E, Gielstrup TC, Behzadi MT, Poulsen LM, Estrup S, Laigaard JP, Andersen C, Mortensen CB, Brand BA, White J, Jarnvig IL, Møller MH, Quist L, Bestle MH, Schønemann-Lund M, Kamper MK, Hindborg M, Hollinger A, Gebhard CE, Zellweger N, Meyhoff CS, Hjort M, Bech LK, Grøfte T, Bundgaard H, Østergaard LHM, Thyø MA, Hildebrandt T, Uslu B, Sølling CG, Møller-Nielsen N, Brøchner AC, Borup M, Okkonen M, Dieperink W, Pedersen UG, Andreasen AS, Buus L, Aslam TN, Winding RR, Schefold JC, Thorup SB, Iversen SA, Engstrøm J, Kjær MN, Rasmussen BS; HOT-ICU Investigators.. Lower or higher oxygenation targets for acute hypoxemic respiratory failure. N Engl J Med. 2021;384(14):1301-11.
65. Madotto F, Rezoagli E, Pham T, Schmidt M, McNicholas B, Protti A, Panwar R, Bellani G, Fan E, van Haren F, Brochard L, Laffey JG; LUNG SAFE Investigators and the ESICM Trials Group. Hyperoxemia and excess oxygen use in early acute respiratory distress syndrome: insights from the LUNG SAFE study. Crit Care. 2020 Mar 31;24(1):125.

66. de Jonge E, Peelen L, Keijzers PJ, Joore H, de Lange D, van der Voort PH, Bosman RJ, de Waal RA, Wesselink R, de Keizer NF. Association between administered oxygen, arterial partial oxygen pressure and mortality in mechanically ventilated intensive care unit patients. Crit Care. 2008;12(6):R156.

67. Palmer E, Post B, Klapaukh R, Marra G, MacCallum NS, Brealey D, Ercole A, Jones A, Ashworth S, Watkinson P, Beale R, Brett SJ, Young JD, Black C, Rashan A, Martin D, Singer M, Harris S. The association between supraphysiologic arterial oxygen levels and mortality in critically ill patients. A multicenter observational cohort study. Am J Respir Crit Care Med. 2019;200(11):1373-80.

68. Kilgannon JH, Jones AE, Shapiro NI, Angelos MG, Milcarek B, Hunter K, Parrillo JE, Trzeciak S; Emergency Medicine Shock Research Network (EMShockNet) Investigators. Association between arterial hyperoxia following resuscitation from cardiac arrest and in-hospital mortality. JAMA. 2010;303(21):2165-71.

69. Boyle AJ, Holmes DN, Hackett J, Gilliland S, McCloskey M, O'Kane CM, Young P, Di Gangi S, McAuley DF. Hyperoxaemia and hypoxaemia are associated with harm in patients with ARDS. BMC Pulm Med. 2021;21(1):285.

70. Knighton DR, Halliday B, Hunt TK. Oxygen as an antibiotic. The effect of inspired oxygen on infection. Arch Surg. 1984;1 19(2):199-204.

71. Knighton DR, Fiegel VD, Halverson T, Schneider S, Brown T, Wells CL. Oxygen as an antibiotic. The effect of inspired oxygen on bacterial clearance. Arch Surg. 1990;125(1):97-100.

72. Smit B, Smulders YM, van der Wouden JC, Oudemans-van Straaten HM, Spoelstra-de Man AME. Hemodynamic effects of acute hyperoxia: systematic review and meta-analysis. Crit Care. 2018;22(1):45.

73. Six S, Jaffal K, Ledoux G, Jaillette E, Wallet F, Nseir S. Hyperoxemia as a risk factor for ventilator-associated pneumonia. Crit Care. 2016;20(1):195

74. Six S, Rouzé A, Pouly O, Poissy J, Wallet F, Preau S, Nseir S. Impact of hyperoxemia on mortality in critically ill patients with ventilator-associated pneumonia. Ann Transl Med. 2018;6(21):417.

75. Asfar P, Schortgen F, Boisramé-Helms J, Charpentier J, Guérot E, Megarbane B, Grimaldi D, Grelon F, Anguel N, Lasocki S, Henry-Lagarrigue M, Gonzalez F, Legay F, Guitton C, Schenck M, Doise JM, Devaquet J, Van Der Linden T, Chatellier D, Rigaud JP, Dellamonica J, Tamion F, Meziani F, Mercat A, Dreyfuss D, Seegers V, Radermacher P; HYPER2S Investigators; REVA research network. Hyperoxia and hypertonic saline in patients with septic shock (HYPERS2S): a two-by-two factorial, multicentre, randomised, clinical trial. Lancet Respir Med. 2017;5(3):180-190.

76. Demiselle J, Wepler M, Hartmann C, Radermacher P, Schortgen F, Meziani F, Singer M, Seegers V, Asfar P; HYPER2S investigators. Hyperoxia toxicity in septic shock patients according to the Sepsis-3 criteria: a post hoc analysis of the HYPER2S trial. Ann Intensive Care. 2018;8(1):90.

77. Young P, Mackle D, Bellomo R, Bailey M, Beasley R, Deane A, Eastwood G, Finfer S, Freebairn R, King V, Linke N, Litton E, McArthur C, McGuinness S, Panwar R, ICU-ROX Investigators the Australian New Zealand Intensive Care Society Clinical Trials Group. Conservative oxygen therapy for mechanically ventilated adults with sepsis: a post hoc analysis of data from the intensive care unit randomized trial comparing two approaches to oxygen therapy (ICU-ROX). Intensive Care Med. 2020;46(1):17-26.

78. Vincent JL, De Backer D. Circulatory shock. N Engl J Med. 2013;369(18):1726-34.

79. Myers RB, Lazaridis C, Jermaine CM, Robertson CS, Rusin CG. Predicting intracranial pressure and brain tissue oxygen crises in patients with severe traumatic brain injury. Crit Care Med. 2016:44(9):1754-61.

80. Pascual JL, Georgoff P, Maloney-Wilensky E, Sims C, Sarani B, Stiefel MF, LeRoux PD, Schwab CW. Reduced brain tissue oxygen in traumatic brain injury: are most commonly used interventions successful? J Trauma. 2011;70(3):535-46.

81. Okonkwo DO, Shutter LA, Moore C, Temkin NR, Puccio AM, Madden CJ, Andaluz N, Chesnut RM, Bullock MR, Grant GA, McGregor J, Weaver M, Jallo J, LeRoux PD, Moberg D, Barber J, Lazaridis C, Diaz-Arrastia RR. 
Brain oxygen optimization in severe traumatic brain injury phase-ll: a phase II randomized trial. Crit Care Med. 2017:45(11):1907-14.

82. Hlatky R, Valadka AB, Gopinath SP, Robertson CS. Brain tissue oxygen tension response to induced hyperoxia reduced in hypoperfused brain. J Neurosurg. 2008;108(1):53-8.

83. Veenith TV, Carter EL, Grossac J, Newcombe VF, Outtrim JG, Nallapareddy S, Lupson V, Correia MM, Mada MM, Williams GB, Menon DK, Coles JP. Use of diffusion tensor imaging to assess the impact of normobaric hyperoxia within at-risk pericontusional tissue after traumatic brain injury. J Cereb Blood Flow Metab. 2014;34(10):1622-7.

84. Quintard H, Patet C, Suys T, Marques-Vidal P, Oddo M. Normobaric hyperoxia is associated with increased cerebral excitotoxicity after severe traumatic brain injury. Neurocrit Care. 2015;22(2):243-50.

85. Davis DP, Meade W, Sise MJ, Kennedy F, Simon F, Tominaga G, Steele J, Coimbra R. Both hypoxemia and extreme hyperoxemia may be detrimental in patients with severe traumatic brain injury. J Neurotrauma. 2009;26(12):2217-23.

86. Raj R, Bendel S, Reinikainen M, Kivisaari R, Siironen J, Lång M, Skrifvars M. Hyperoxemia and long-term outcome after traumatic brain injury. Crit Care. 2013;17(4):R177.

87. Rincon F, Kang J, Maltenfort M, Vibbert M, Urtecho J, Athar MK, Jallo J, Pineda CC, Tzeng D, McBride W, Bell R. Association between hyperoxia and mortality after stroke: a multicenter cohort study. Crit Care Med. 2014;42(2):387-96.

88. López HV, Vivas MF, Ruiz RN, Martínez JR, Navaridas BG, Villa MG, Lázaro CL, Rubio RJ, Ortiz AM, Lacal LA, Diéguez AM. Association between post-procedural hyperoxia and poor functional outcome after mechanical thrombectomy for ischemic stroke: an observational study. Ann Intensive Care. 2019;9(1):59.

89. Fukuda S, Koga Y, Fujita M, Suehiro E, Kaneda K, Oda Y, Ishihara H, Suzuki $M$, Tsuruta R. Hyperoxemia during the hyperacute phase of aneurysmal subarachnoid hemorrhage is associated with delayed cerebral ischemia and poor outcome: a retrospective observational study. J Neurosurg. 2021;134(1):25-32.

90. Reynolds RA, Amin SN, Jonathan SV, Tang AR, Lan M, Wang C, Bastarache JA, Ware LB, Thompson RC. Hyperoxemia and cerebral vasospasm in aneurysmal subarachnoid hemorrhage. Neurocrit Care. 2021;35(1):30-8

91. Lång M, Raj R, Skrifvars MB, Koivisto T, Lehto H, Kivisaari R, von Und Zu Fraunberg M, Reinikainen M, Bendel S. Early Moderate Hyperoxemia Does Not Predict Outcome After Aneurysmal Subarachnoid Hemorrhage. Neurosurgery. 2016;78(4):540-5.

92. Roffe C, Nevatte T, Sim J, Bishop J, Ives N, Ferdinand P, Gray R; Stroke Oxygen Study Investigators and the Stroke Oxygen Study Collaborative Group. Effect of routine low-dose oxygen supplementation on death and disability in adults with acute stroke: the stroke oxygen study randomized clinical trial. JAMA. 2017;318(12):1125-35.

93. Young P, Beasley R, Bailey M, Bellomo R, Eastwood GM, Nichol A, Pilcher DV, Yunos NM, Egi M, Hart GK, Reade MC, Cooper DJ; Study of Oxygen in Critical Care (SOCC) Group. The association between early arterial oxygenation and mortality in ventilated patients with acute ischaemic stroke. Crit Care Resusc. 2012;14(1):14-9.

94. O'Briain D, Nickson C, Pilcher DV, Udy AA. Early hyperoxia in patients with traumatic brain injury admitted to intensive care in Australia and New Zealand: a retrospective multicenter cohort study. Neurocrit Care. 2018;29(3):443-51.

95. Weeden M, Bailey M, Gabbe B, Pilcher D, Bellomo R, Udy A. Functional outcomes in patients admitted to the intensive care unit with traumatic brain injury and exposed to hyperoxia: a retrospective multicentre cohort study. Neurocrit Care. 2021;34(2):441-8.

96. Alali AS, Temkin N, Vavilala MS, Lele AV, Barber J, Dikmen S, Chesnut RM. Matching early arterial oxygenation to long-term outcome in severe traumatic brain injury: target values. J Neurosurg. 2019;132(2):537-44.

97. Li N, Wu L, Zhao W, Dornbos D, Wu C, Li W, Wu D, Ding J, Ding Y, Xie $Y$, Ji X. Efficacy and safety of normobaric hyperoxia combined with intravenous thrombolysis on acute ischemic stroke patients. Neurol Res. 2021;15:1-6. https://doi.org/10.1080/01616412.2021.1939234.

98. Singhal AB, Benner T, Roccatagliata L, Koroshetz WJ, Schaefer PW, Lo EH, Buonanno FS, Gonzalez RG, Sorensen AG. A pilot study of normobaric oxygen therapy in acute ischemic stroke. Stroke. 2005;36(4):797-802.
99. Wu O, Benner T, Roccatagliata L, Zhu M, Schaefer PW, Sorensen AG, Singhal $A B$. Evaluating effects of normobaric oxygen therapy in acute stroke with MRI-based predictive models. Med Gas Res. 2012;2(1):5.

100. Padma MV, Bhasin A, Bhatia R, Garg A, Singh MB, Tripathi M, Prasad K. Normobaric oxygen therapy in acute ischemic stroke: A pilot study in Indian patients. Ann Indian Acad Neurol. 2010;13(4):284-8.

101. Taher A, Pilehvari Z, Poorolajal J, Aghajanloo M. Effects of normobaric hyperoxia in traumatic brain injury: a randomized controlled clinical trial. Trauma Mon. 2016;21(1):e26772.

102. Lång M, Skrifvars MB, Siironen J, Tanskanen P, Ala-Peijari M, Koivisto T, Djafarzadeh S, S Bendel S. A pilot study of hyperoxemia on neurological injury, inflammation and oxidative stress. Acta Anaesthesiol Scand. 2018;62(6):801-10.

103. Barbee RW, Reynolds PS, Ward KR. Assessing shock resuscitation strategies by oxygen debt repayment. Shock. 2010;33(2):113-22.

104. Dyson A, Simon F, Seifritz A, Zimmerling O, Matallo J, Calzia E, Radermacher $P$, Singer M. Bladder tissue oxygen tension monitoring in pigs subjected to a range of cardiorespiratory and pharmacological challenges. Intensive Care Med. 2012;38(11):1868-76.

105. Knöller E, Stenzel T, Broeskamp F, Hornung R, Scheuerle A, McCook O, Wachter U, Vogt JA, Matallo J, Wepler M, Gässler H, Gröger M, Matejovic M, Calzia E, Lampl L, Georgieff M, Möller P, Asfar P, Radermacher P, Hafner S. Effects of hyperoxia and mild therapeutic hypothermia during resuscitation from porcine hemorrhagic shock. Crit Care Med. 2016:44:e264-77.

106. Hartmann C, Loconte M, Antonucci E, Holzhauser M, Hölle T, Katzsch D, Merz T, McCook O, Wachter U, Vogt JA, Hoffmann A, Wepler M, Gröger M, Matejovic M, Calzia E, Georgieff M, Asfar P, Radermacher P, Nussbaum BL. Effects of hyperoxia during resuscitation from hemorrhagic shock in swine with preexisting coronary artery disease. Crit Care Med. 2017:45(12):e1270-9.

107. Leitch P, Hudson AL, Griggs JE, Stolmeijer R, Lyon RM, Ter Avest E; Air Ambulance Kent Surrey Sussex. Incidence of hyperoxia in trauma patients receiving pre-hospital emergency anaesthesia: results of a 5-year retrospective analysis. Scand J Trauma Resusc Emerg Med. 2021;29(1):134.

108. Russell DW, Janz DR, Emerson WL, May AK, Bernard GR, Zhao Z, Koyama T, Ware LB. Early exposure to hyperoxia and mortality in critically ill patients with severe traumatic injuries. BMC Pulm Med. 2017;17(1):29.

109. Page D, Ablordeppey E, Wessman BT, Mohr NM, Trzeciak S, Kollef MH, Roberts BW, Fuller BM. Emergency department hyperoxia is associated with increased mortality in mechanically ventilated patients: a cohort study. Crit Care. 2018;22(1):9.

110. Baekgaard J, Abback PS, Boubaya M, Moyer JD, Garrigue D, Raux M, Champigneulle B, Dubreuil G, Pottecher J, Laitselart P, Laloum F, BlochQueyrat C, Adnet F, Paugam-Burtz C; Traumabase ${ }^{\circledR}$ Study Group. Early hyperoxemia is associated with lower adjusted mortality after severe trauma: Results from a French registry. Crit Care. 2020;24(1):604.

111. Duclos G, Rivory A, Rességuier N, Hammad E, Vigne C, Meresse Z, Pastène B, Xavier- D'journo XB, Jaber S, Zieleskiewicz L, Leone M. Effect of early hyperoxemia on the outcome in servere blunt chest trauma: $A$ propensity score-based analysis of a single-center retrospective cohort. J Crit Care. 2021:63:179-86.

112. Christensen MA, Steinmetz J, Velmahos G, Rasmussen LS. Supplemental oxygen therapy in trauma patients: An exploratory registry-based study. Acta Anaesthesiol Scand. 2021. https://doi.org/10.1111/aas.13829.

113. Yamamoto R, Fujishima S, Sasaki J, Gando S, Saitoh D, Shiraishi A, Kushimoto S, Ogura H, Abe T, Mayumi T, Kotani J, Nakada TA, Shiino Y, Tarui T, Okamoto K, Sakamoto Y, Shiraishi SI, Takuma K, Tsuruta R, Masuno T, Takeyama N, Yamashita N, Ikeda H, Ueyama M, Hifumi T, Yamakawa K, Hagiwara A, Otomo Y; Japanese Association for Acute Medicine (JAAM) Focused Outcomes Research in Emergency Care in Acute Respiratory Distress Syndrome, Sepsis and Trauma (FORECAST) Study Group. Hyperoxemia during resuscitation of trauma patients and increased intensive care unit length of stay: inverse probability of treatment weighting analysis. World J Emerg Surg. 2021;16(1):19.

114. Douin DJ, Anderson EL, Dylla L, Rice JD, Jackson CL, Wright FL, Bebarta VS, Schauer SG, Ginde AA. Association between hyperoxia, supplemental oxygen, and mortality in critically injured patients. Crit Care Explor. 2021;3(5):e0418. 
115. Imberti R, Bellinzona G, Riccardi F, Pagani M, Langer M. Cerebral perfusion pressure and cerebral tissue oxygen tension in a patient during cardiopulmonary resuscitation. Intensive Care Med Intensive Care Med. 2003;29(6):1016-9.

116. Nelskylä A, Nurmi J, Jousi M, Schramko A, Mervaala E, Ristagno G, Skrifvars MB. The effect of $50 \%$ compared to $100 \%$ inspired oxygen fraction on brain oxygenation and post cardiac arrest mitochondrial function in experimental cardiac arrest. Resuscitation. 2017;116:1-7.

117. Soar J, Nolan JP, Böttiger BW, Perkins GD, Lott C, Carli P, Pellis T, Sandroni C, Skrifvars MB, Smith GB, Sunde K, Deakin CD, Adult advanced life support section Collaborators. European Resuscitation Council Guidelines for Resuscitation,. Section 3. Adult advanced life support Resuscitation. 2015;2015(95):100-47.

118. Spindelboeck W, Gemes G, Strasser C, Toescher K, Kores B, Metnitz $P$, Haas J, Prause G. Arterial blood gases during and their dynamic changes after cardiopulmonary resuscitation: A prospective clinical study. Resuscitation. 2016;106:24-9.

119. Spindelboeck W, Schindler O, Moser A, Hausler F, Wallner S, Strasser C, Haas J, Gemes G, Prause G. Increasing arterial oxygen partial pressure during cardiopulmonary resuscitation is associated with improved rates of hospital admission. Resuscitation. 2013;84:770-5.

120. Young P, Bailey M, Bellomo R, Bernard S, Dicker B, Freebairn R, Henderson S, Mackle D, McArthur C, McGuinness S, Smith T, Swain A, Weatherall M, Beasley R. HyperOxic Therapy OR NormOxic Therapy after out-of-hospital cardiac arrest (HOT OR NOT): a randomised controlled feasibility trial. Resuscitation. 2014;85:1686-91.

121. Kilgannon JH, Jones AE, Parrillo JE, Dellinger RP, Milcarek B, Hunter K, Shapiro NI, Trzeciak S, Emergency Medicine Shock Research Network (EMShockNet) Investigators. Relationship between supranormal oxygen tension and outcome after resuscitation from cardiac arrest. Circulation. 2011:123(23):2717-22.

122. Janz DR, Hollenbeck RD, Pollock JS, McPherson JA, Rice TW. Hyperoxia is associated with increased mortality in patients treated with mild therapeutic hypothermia after sudden cardiac arrest. Crit Care Med. 2012:40(12):3135-9.

123. Wang $\mathrm{CH}$, Huang $\mathrm{CH}$, Chang WT, Tsai MS, Lu TC, Yu PH, Wang AY, Chen NC, Chen WJ. Association between early arterial blood gas tensions and neurological outcome in adult patients following in-hospital cardiac arrest. Resuscitation. 2015;89:1-7.

124. Roberts BW, Kilgannon JH, Hunter BR, Puskarich MA, Pierce L, Donnino M, Leary M, Kline JA, Jones AE, Shapiro NI, Abella BS, Trzeciak S. Association between early hyperoxia exposure after resuscitation from cardiac arrest and neurological disability: prospective multicenter protocoldirected cohort study. Circulation. 2018;137(20):2114-24.

125. Bellomo R, Bailey M, Eastwood GM, Nichol A, Pilcher D, Hart GK, Reade MC, Egi M, Cooper DJ; Study of Oxygen in Critical Care (SOCC) Group. Arterial hyperoxia and in-hospital mortality after resuscitation from cardiac arrest. Crit Care. 2011;15(2):R90.

126. Vaahersalo J, Bendel S, Reinikainen M, Kurola J, Tiainen M, Raj R, Pettilä $\checkmark$, Varpula T, Skrifvars MB, FINNRESUSCI Study Group. Arterial blood gas tensions after resuscitation from out-of-hospital cardiac arrest: associations with long-term neurologic outcome. Crit Care Med. 2014:42(6):1463-70

127. Johnson NJ, Dodampahala K, Rosselot B, Perman SM, Mikkelsen ME, Goyal M, Gaieski DF, Grossestreuer AV. The association between arterial oxygen tension and neurological outcome after cardiac arrest. Ther Hypothermia Temp Manag. 2017:7(1):36-41.

128. Wang HE, Prince DK, Drennan IR, Grunau B, Carlbom DJ, Johnson N, Hansen M, Elmer J, Christenson J, Kudenchuk P, Aufderheide T, Weisfeldt M, Idris A, Trzeciak S, Kurz M, Rittenberger JC, Griffiths D, Jasti J, May S; Resuscitation Outcomes Consortium (ROC) Investigators. Postresuscitation arterial oxygen and carbon dioxide and outcomes after out-of-hospital cardiac arrest. Resuscitation. 2017;120:113-118.

129. Ebner F, Ullén S, Åneman A, Cronberg T, Mattsson N, Friberg H, Hassager C, Kjærgaard J, Kuiper M, Pelosi P, Undén J, Wise MP, Wetterslev J, Nielsen N. Associations between partial pressure of oxygen and neurological outcome in out-of-hospital cardiac arrest patients: an explorative analysis of a randomized trial. Crit Care. 2019;23(1):30.

130. Young PJ, Bailey M, Bellomo R, Bernard S, Bray J, Jakkula P, Kuisma M, Mackle D, Martin D, Nolan JP, Panwar R, Reinikainen M, Skrifvars MB, Thomas M. Conservative or liberal oxygen therapy in adults after cardiac arrest: An individual-level patient data meta-analysis of randomised controlled trials. Resuscitation. 2020;157:15-22.

131. Holmberg MJ, Nicholson T, Nolan JP, Schexnayder S, Reynolds J, Nation K, Welsford M, Morley P, Soar J, Berg KM; Adult Pediatric Advanced Life Support Task Forces at the International Liaison Committee on Resuscitation (ILCOR). Oxygenation and ventilation targets after cardiac arrest: A systematic review and meta-analysis. Resuscitation. 2020;152:107-15.

132. Jakkula P, Reinikainen M, Hästbacka J, Loisa P, Tiainen M, Pettilä V, Toppila J, Lähde M, Bäcklund M, Okkonen M, Bendel S, Birkelund T, Pulkkinen A, Heinonen J, Tikka T, Skrifvars MB, COMACARE study group. Targeting two different levels of both arterial carbon dioxide and arterial oxygen after cardiac arrest and resuscitation: a randomised pilot trial. Intensive Care Med. 2018:44(12):2112-21.

133. Wihersaari L, Ashton NJ, Reinikainen M, Jakkula P, Pettilä V, Hastbacka J, Tiainen M, Loisa P, Friberg H, Cronberg T, Blennow K, Zetterberg H, Skrifvars MB, COMACARE STUDY GROUP. Neurofilament light as an outcome predictor after cardiac arrest: a post hoc analysis of the COMACARE trial. Intensive Care Med. 2021:47(1):39-48.

134. Young P, Mackle D, Bellomo R, Bailey M, Beasley R, Deane A, Eastwood G, Finfer S, Ross Freebairn R, King V, Linke N, Litton E, McArthur C, McGuinness S, Panwar R, ICU-ROX Investigators the Australian New Zealand Intensive Care Society Clinical Trials Group. Conservative oxygen therapy for mechanically ventilated adults with suspected hypoxic ischaemic encephalopathy. Intensive Care Med. 2020;46(1):2411-22.

135. Nolan JP, Sandroni C, Böttiger BW, Cariou A, Cronberg T, Friberg H, Genbrugge C, Haywood K, Lilja G, Moulaert VRM, Nikolaou N, Mariero Olasveengen T, Skrifvars MB, Taccone F, Soar J. European Resuscitation Council and European Society of Intensive Care Medicine Guidelines 2021: Post-resuscitation care. Resuscitation. 2021:161:220-69.

136. Beasley R, Aldington S, Weatherall M, Robinson G, McHaffie D. Oxygen therapy in myocardial infarction: an historical perspective. J R Soc Med. 2007;100:130-3

137. McNulty PH, King N, Scott S, Hartman G, McCann J, Kozak M, Chambers CE, Demers LM, Sinoway LI. Effects of supplemental oxygen administration on coronary blood flow in patients undergoing cardiac catheterization. Am J Physiol Heart Circ Physiol. 2005;288(3):H1057-62.

138. Hofmann R, James SK, Jernberg T, Lindahl B, Erlinge D, Witt N, Arefalk G, Frick M, Alfredsson J, Nilsson L, Ravn-Fischer A, Omerovic E, Kellerth T, Sparv D, Ekelund U, Linder R, Ekström M, Lauermann J, Haaga U, Pernow J, Östlund O, Herlitz J, Svensson L; DETO2X-SWEDEHEART Investigators. Oxygen therapy in suspected acute myocardial infarction. N Engl J Med. 2017;377(13):1240-9.

139. Stub D, Smith K, Bernard S, Nehme Z, Stephenson M, Bray JE, Cameron P, Barger B, Ellims AH, Taylor AJ, Meredith IT, Kaye DM; AVOID Investigators. Air versus oxygen in ST-segment-elevation myocardial infarction. Circulation. 2015:131(24):2143-50.

140. Stewart RAH, Jones $P$, Dicker B, Jiang Y, Smith T, Swain A, Kerr A, Scott T, Smyth D, Ranchord A, Edmond J, Than M, Webster M, White HD, Devlin G. High flow oxygen and risk of mortality in patients with a suspected acute coronary syndrome: pragmatic, cluster randomised, crossover trial. BMJ. 2021;372:n355.

141. Hopf HW, Hunt TK, West JM, Blomquist P, Goodson WH, Jensen JA, Jonsson K, Paty PB, Rabkin JM, Upton RA, von Smitten K, Whitney JD. Wound tissue oxygen tension predicts the risk of wound infection in surgical patients. Arch Surg. 1997;132(9):997-1004.

142. Greif R, Akça O, Horn EP, Kurz A, Sessler DI, Outcomes Research Group. Supplemental perioperative oxygen to reduce the incidence of surgical-wound infection. N Engl J Med. 2000;342(3):161-7.

143. Meyhoff CS, Wetterslev J, Jorgensen LN, Henneberg SW, Høgdall C, Lundvall L, Svendsen PE, Mollerup H, Lunn TH, Simonsen I, Martinsen KR, Pulawska T, Bundgaard L, Bugge L, Hansen EG, Riber C, Gocht-Jensen P, Walker LR, Bendtsen A, Johansson G, Skovgaard N, Heltø K, Poukinski A, Korshin A, Walli A, Bulut M, Carlsson PS, Rodt SA, Lundbech LB, Rask H, Buch N, Perdawid SK, Reza J, Jensen KV, Carlsen CG, Jensen FS, Rasmussen LS, PROXI Trial Group29397118. Effect of high perioperative oxygen fraction on surgical site infection and pulmonary complications after abdominal surgery: the PROXI randomized clinical trial. JAMA. 2009;302(14):1543-50.

144. Kurz A, Kopyeva T, Suliman I, Podolyak A, You J, Lewis B, Vlah C, Khatib R, Keebler A, Reigert R, Seuffert M, Muzie L, Drahuschak S, Gorgun E, Stocchi L, Turan A, Sessler DI. Supplemental oxygen and surgical-site 
infections: an alternating intervention controlled trial. Br J Anaesth. 2018;120(1):117-26.

145. Meyhoff CS, Jorgensen LN, Wetterslev J, Christensen KB, Rasmussen LS; PROXI Trial Group. Increased long-term mortality after a high perioperative inspiratory oxygen fraction during abdominal surgery: follow-up of a randomized clinical trial. Anesth Analg. 2012;115(4):849-54.

146. Meyhoff CS, Jorgensen LN, Wetterslev J, Siersma VD, Rasmussen LS; PROXI Trial Group. Risk of new or recurrent cancer after a high perioperative inspiratory oxygen fraction during abdominal surgery. $\mathrm{Br}$ J Anaesth. 2014;113 Suppl 1:i74-i81.

147. Edmark L, Kostova-Aherdan K, Enlund M, Hedenstierna G. Optimal oxygen concentration during induction of general anesthesia. Anesthesiology. 2003;98(1):28-33.

148. Hedenstierna G. Oxygen and anesthesia: what lung do we deliver to the post-operative ward? Acta Anaesthesiol Scand. 2012;56(6):675-85.

149. LAS Vegas investigators. Epidemiology, practice of ventilation and outcome for patients at increased risk of postoperative pulmonary complications: LAS VEGAS - an observational study in 29 countries. Eur J Anaesthesiol. 2017;34(8):492-507.

150. Morkane CM, McKenna H, Cumpstey AF, Oldman AH, Grocott MPW, Martin DS; Pan London Perioperative Audit and Research Network (PLAN); South Coast Perioperative Audit and Research Collaboration (SPARC). Intraoperative oxygenation in adult patients undergoing surgery (iOPS): a retrospective observational study across 29 UK hospitals. Perioper Med. $2018 \mathrm{Jul}$ 24;7:17.

151. Staehr-Rye AK, Meyhoff CS, Scheffenbichler FT, Vidal Melo MF, Gätke MR, Walsh JL, K Ladha KS, Grabitz SD, Nikolov MI, Kurth T, Rasmussen LS, M Eikermann M. High intraoperative inspiratory oxygen fraction and risk of major respiratory complications. Br J Anaesth. 2017;119(1):140-9.

152. Mattishent $K$, Thavarajah M, Sinha A, Peel A, Egger M, Solomkin J, de Jonge S, Latif A, Berenholtz S, Allegranzi B, Loke YK. Safety of $80 \%$ vs $30-35 \%$ fraction of inspired oxygen in patients undergoing surgery: a systematic review and meta-analysis. Br J Anaesth. 2019;122(3):311-24.

153. de Jonge S, Egger M, Latif A, Loke YK, Berenholtz S, Boermeester M, Allegranzi B, Solomkin J. Effectiveness of $80 \%$ vs $30-35 \%$ fraction of inspired oxygen in patients undergoing surgery: an updated systematic review and meta-analysis. Br J Anaesth. 2019;122(3):325-34.

154. Meyhoff CS. Perioperative hyperoxia: why guidelines, research and clinical practice collide. Br J Anaesth. 2019;122(3):289-91.

155. Weenink RP, W de Jonge $S$, Hulst RA, Wingelaar TT, van Ooij PJAM, Immink RV, Preckel B, Hollmann MW. Perioperative hyperoxyphobia: justified or not? Benefits and harms of hyperoxia during surgery. J Clin Med. 2020;9(3):642.

156. Bickel A, Gurevits M, Vamos R, Ivry S, Eitan A. Perioperative hyperoxygenation and wound site infection following surgery for acute appendicitis: a randomized, prospective, controlled trial. Arch Surg. 2011;146(4):464-70.

157. Barbateskovic M, Schjørring OL, Krauss SR, Jakobsen JC, Meyhoff CS, Dahl RM, Rasmussen BD, Perner A, Wetterslev J. Higher versus lower fraction of inspired oxygen or targets of arterial oxygenation for adults admitted to the intensive care unit. Cochrane Database Syst Rev. 2019 Nov 27;2019(11):CD012631.

158. Lassen ML, Risgaard B, Baekgaard JS, Rasmussen LS. Determining a safe upper limit of oxygen supplementation for adult patients: a systematic review. BMJ Open 2021;11:e045057.

159. Rockswold SB, Rockswold GL, Zaun DA, Liu J. A prospective, randomized Phase II clinical trial to evaluate the effect of combined hyperbaric and normobaric hyperoxia on cerebral metabolism, intracranial pressure, oxygen toxicity, and clinical outcome in severe traumatic brain injury. J Neurosurg. 2013;118(6):1317-28.

160. Lopez MG, Pandharipande P, Morse J, Shotwell MS, Milne GL, Pretorius $M$, Shaw AD, Roberts $L$, Billings FT. Intraoperative cerebral oxygenation, oxidative injury, and delirium following cardiac surgery. Free Radic Biol Med. 2017;103:192-8.

161. Carr AC, Spencer E, Mackle D, Hunt A, Judd H, Mehrtens J, Parker K, Stockwell Z, Gale C, Beaumont M, Kaur S, Bihari S, Young PJ. The effect of conservative oxygen therapy on systemic biomarkers of oxidative stress in critically ill patients. Free Radic Biol Med. 2020;160:13-8.

162. Matallo J, Vogt J, McCook O, Wachter U, Tillmans F, Groeger M, Szabo C, Georgieff M, Radermacher P, Calzia E. Sulfide-inhibition of mitochondrial respiration at very low oxygen concentrations. Nitric Oxide. 2014;41:79-84.

\section{Publisher's Note}

Springer Nature remains neutral with regard to jurisdictional claims in published maps and institutional affiliations.
Ready to submit your research? Choose BMC and benefit from:

- fast, convenient online submission

- thorough peer review by experienced researchers in your field

- rapid publication on acceptance

- support for research data, including large and complex data types

- gold Open Access which fosters wider collaboration and increased citations

- maximum visibility for your research: over $100 \mathrm{M}$ website views per year

At BMC, research is always in progress.

Learn more biomedcentral.com/submissions 